\title{
Spatial-Temporal Change of Actual Evapotranspiration and the Causes Based on the Advection-Aridity Model in the Weihe River Basin, China
}

\author{
Ruirui Xu ${ }^{1}$, Peng Gao ${ }^{1,2, *}$, Xingmin $\mathrm{Mu}^{1,2}$ and Chaojun $\mathrm{Gu}^{3}$ \\ 1 State Key Laboratory of Soil Erosion and Dryland Farming on the Loess Plateau, Institute of Soil and Water \\ Conservation, Northwest A\&F University, Yangling 712100, China; ruirui-xu0302@139.com (R.X.); \\ xmmu@ms.iswc.ac.cn (X.M.) \\ 2 State Key Laboratory of Soil Erosion and Dryland Farming on the Loess Plateau, Institute of Soil and Water \\ Conservation, Chinese Academy of Sciences \& Ministry of Water Resources, Yangling 712100, China \\ 3 Yangtze Soil Conservation Monitoring Center, Changjiang Water Resources Commission, \\ Wuhan 430010, China; chaojungu1990@163.com \\ * Correspondence: gaopeng@ms.iswc.ac.cn
}

check for updates

Citation: Xu, R.; Gao, P.; Mu, X.; Gu, C. Spatial-Temporal Change of Actual Evapotranspiration and the Causes Based on the Advection-Aridity Model in the Weihe River Basin, China. Water 2021, 13, 303.

https:/ / doi.org/10.3390/w13030303

Academic Editor: Fernando António Leal Pacheco

Received: 10 November 2020

Accepted: 20 January 2021

Published: 27 January 2021

Publisher's Note: MDPI stays neutral with regard to jurisdictional claims in published maps and institutional affiliations.

Copyright: (c) 2021 by the authors. Licensee MDPI, Basel, Switzerland. This article is an open access article distributed under the terms and conditions of the Creative Commons Attribution (CC BY) license (https:/ / creativecommons.org/licenses/by/ $4.0 /)$.

\begin{abstract}
Evapotranspiration is a key process between the atmospheric hydrological cycle and the energy cycle, which has a great significance in understanding climate change and the rational use of water resources, especially for the Weihe River basin (WRB) (a basin in China experiencing a shortage of water resources). We investigated the spatial-temporal change of actual evapotranspiration $\left(E T_{\mathrm{a}}\right)$ based on the daily meteorological variables of 22 meteorological stations and the annual streamflow of three hydrological stations from 1970 to 2018 in the WRB. The contributions of key meteorological variables to $E T_{\mathrm{a}}$ changes and the sensitivity coefficient are also quantified. The temporal trends of $E T_{\mathrm{a}}$ showed an increasing trend from 1970 to 2018, and the spatial distribution of $E T_{\mathrm{a}}$ increased from northwest to southeast in the WRB. Increasing trends were detected in the multi-year average, spring, and winter, but only a few stations passed the significance test. Summer and autumn showed a decreasing trend, but this trend was not significant. Solar radiation is the most sensitive meteorological variable, followed by vapor pressure, wind speed, and mean temperature. Vapor pressure contributes the most to $E T_{\mathrm{a}}$ changes, followed by solar radiation. In general, vapor pressure (relative humidity) is the dominant meteorological factor affecting $E T_{\mathrm{a}}$ in the WRB. In addition to meteorological factors, the $E T_{\mathrm{a}}$ is also affected by combined and complicated factors caused by precipitation and human activities. As an important part of the hydrological cycle, $E T_{\mathrm{a}}$ has important research significance for water resources management, economy, agriculture, and ecology and results of this study may be helpful to further clarify the climate change and human activities impacts on the basin hydrological cycle.
\end{abstract}

Keywords: evapotranspiration; complementary relationship; Advection-Aridity model; Weihe River Basin

\section{Introduction}

Evapotranspiration is a complex hydrological process, which closely links surface water balance and energy balance and is an important component of the hydrological process and energy cycle in the ecosystem [1]. It is estimated that with land surface evapotranspiration of more than $6 \times 10^{4} \mathrm{~km}^{3}$, nearly $70 \%$ of the precipitation on land will return to the atmosphere in the form of evapotranspiration each year [2]. The changes in climate factors and terrestrial surfaces (vegetation and soil characteristics) are the most direct factors affecting evapotranspiration during the hydrological cycle [3,4]. Accurately estimating the changes in $E T_{\mathrm{a}}$ and the attribution of different meteorological factors to $E T_{\mathrm{a}}$ is significant for the research of regional climate change, water resource management, and the construction of water conservancy projects. Almost every aspect of forestry, agriculture, and 
water resource allocation is related to terrestrial and water surface evapotranspiration [5-8]. Therefore, the study of the regular patterns and mechanisms related to evapotranspiration is becoming increasingly important.

In recent centuries, the global climate has experienced a significant warming trend, and the issue of climate change has drawn much attention from the public, academic circles, and governments [9]. The fifth report of the IPCC noted that during the years from 1880 to 2012 , the global average temperature on land and sea increased by $0.85^{\circ} \mathrm{C}$. According to paleo climatological data, the years from 1983 to 2012 may have been the warmest in the past 1400 years [10]. In this context, it is believed that global warming will dry out the surface atmosphere and increase the evapotranspiration of the soil surface and the crop, which will cause a series of water cycle changes [1,11]. A large number of current results show that there has been a continuous decrease in the evapotranspiration of evaporating pans around the world. The rate of this decrease was about $-1 \sim-5 \mathrm{~mm} \cdot \mathrm{a}^{-10}$ in the past 50 years [12-14]. The potential evapotranspiration $\left(E T_{\mathrm{p}}\right)$ in many countries and regions also shows a decreasing trend, while the temperature shows an increasing trend: Italy [15], India [16], Australia [17], Israel [12], New Zealand [18], the Canadian Prairies [19], and Japan [20], as well as some regions of China, have observed the same phenomenon [21-23]. Roderick (2002) called this the "evapotranspiration paradox" for the first time, as a hydrological phenomenon featuring a significant increase in air temperature accompanying a significant decrease in evapotranspiration [24]. The same phenomenon was also reported in studies on the analysis of $E T_{p}$ and the actual evapotranspiration $E T_{\mathrm{a}}$, such as the reference evapotranspiration in the middle and southwest areas of the Yellow River Basin [25]; potential and pan evapotranspiration in the Changjiang (Yangtze River) catchment [26]; $E T_{p}$ in the eastern plain area of the Aksu River Basin [27]; $E T_{\mathrm{a}}$ in the pearl river basin [28]; and $E T_{\mathrm{a}}$ in the Yangtze River [29]. The results of existing studies showed that the attributions of different factors to the trend of evapotranspiration are inconsistent among different studies. Some studies reported solar radiation was the dominant factor for the decrease of evapotranspiration in the Iran [30], northeast India [31] and middlelower Yellow River Plain [25]; Liu [32] observed a decrease of evapotranspiration in the Haihe River Basin attributed to wind speed; and some other studies reported that relative humidity is the dominant factor decreasing evapotranspiration in the Aksu and Heihe River Basins [27,33]. In addition, Irmak et al. [34] and Jung et al. [35] found that limited moisture supply could be the dominant factor driving changes in $E T_{\mathrm{a}}$.

During the past several decades, considerable attention has been given to the tendency, spatiotemporal distribution, and influencing factors of pan evapotranspiration $\left(E T_{\text {pan }}\right)$ and $E T_{p}$. Only a few studies have focused on the long-term changes and driving factors of $E T_{a}$ changes, and it is difficult to obtain sufficient and reliable data for $E T_{\mathrm{a}}$ at a large scale using fixed meteorological observatories. The current estimation of $E T_{\mathrm{a}}$ mainly relies on model estimations and satellite data because lysimeters are costly to install and maintain [36,37]. The water balance method is also used to estimate the $E T_{\mathrm{a}}$, but it cannot be applied to situ measurements and needs mass data (e.g., the water consumption of human activities); moreover, some data are not available to the public. Therefore, this method cannot be used in the spatial analysis of $E T_{\mathrm{a}}$ [38]. In 1963, Bouchet first outlined the complementary hypothesis that the relationship between $E T_{\mathrm{a}}$ and evapotranspiration capacity $\left(E T_{p}\right)$ in a given area are complementary [39]. This complementary relationship states that, over areas at a regional scale and away from any sharp environmental discontinuities, the external energy will remain unchanged. With adequate water status, the process of $E T_{\mathrm{a}}$ will increase with an increase of the water supply; under this condition, $E T_{\mathrm{a}}$ will eventually equal $E T_{p}$, which is defined as wet surface evapotranspiration $\left(E T_{\mathrm{w}}\right)$ [40]. Once $E T_{\mathrm{a}}$ decreases as the water supply becomes less abundant, the air becomes drier, and the excess energy heats up the atmosphere, leading to an increase in $E T_{\mathrm{p}}$ and excess energy equal to the increase in $E T_{p}$-i.e., the results of the complementary relationship between $E T_{p}$ and $E T_{a}$. This phenomenon can be applied to estimate $E T_{\mathrm{a}}$ with routinely recorded weather data without the need for additional, less common measurements of the moisture status of the 
vegetation or soil. As one of the relevant methods, the Advection-Aridity (AA) model has been verified in many regions [40-42]. This method relies solely on routine meteorological observations. Local temperature and humidity gradients in the atmospheric boundary layer respond to - and obviate the necessity for information regarding - the conditions of moisture availability at the surface. These models bypass the complex and poorly understood soilplant processes and thus do not require data on soil moisture, stomatal resistance properties of the vegetation, or any other aridity measures, nor do they require the local calibration of parameters, beyond those built into the models. Therefore, this method is the practical and easier preferred method relatively used in the calculate of $E T_{\mathrm{a}}$.

The Weihe River Basin (WRB) is located in the transition area from semi-arid to semi-humid in an economically developed area in Northwest China, which is also an ecologically fragile area. In recent years, under the influence of climate warming and human activities, the ecological environment of the basin has been rapidly degraded. Most of the existing studies on hydrology and water resources have been done on precipitation [43,44], runoff [45], and $E T_{p}$ in this basin [46,47], with few studies on $E T_{\mathrm{a}}$. Therefore, the main objectives of this study were to (i) analyze the spatial distribution and temporal variation of $E T_{\mathrm{a}}$; (ii) quantitatively assess the impacts of climate variables on $E T_{\mathrm{a}}$, including the degree of sensitivity and contributions of meteorological factors; and (iii) determine the dominant climatic variables that affect the changes of $E T_{\mathrm{a}}$. The results derived from this study will help us better estimate and analyze the spatial and temporal variations of $E T_{a}$ in this region. This study provides a foundation for understanding the causes of drought and flooding, developing scientific irrigation processes and protecting ecological systems, and improving the utilization rate of water resources in this basin.

\section{Study Area and Dataset}

\subsection{Study Area}

As the largest tributary of the Yellow River, the WRB is located in the lower midstream of the Yellow River. The total area is approximately $1.348 \times 10^{5} \mathrm{~km}^{2}$, and the main stream is $818 \mathrm{~km}$ in length. The basin originates from the Niaoshu Mountain of Gansu Province and Baiyu Mountain in the north, reaches Tongguan in the east and the Qinling Mountains in the south, and flows through the three provinces of Shaanxi, Gansu, and Ningxia. The basin is divided into three larger sub-basins with distinct geographic and climatic conditions: the Wei River, the Jing River, and the Beiluo River, known as the Jing-Luo-Wei Region. Among them, the Wei River has the largest area, $7.23 \times 10^{4} \mathrm{~km}^{2}$, and is located to the south of the whole basin with a long east-west direction belonging to the Guanzhong Plain. Jing River is the next largest, with an area of $4.54 \times 10^{4} \mathrm{~km}^{2}$, and is located on the north bank. The smallest area is the Beiluo River, $2.69 \times 10^{4} \mathrm{~km}^{2}$, located in the eastern part of the whole basin and accounting for $20 \%$ of the total basin area. The Wei River Basin is located in the transition zone between arid and humid regions. It belongs to a typical continental monsoon climate, making it dry and cold in winter and humid and hot in summer. The average annual rainfall in the area is $572 \mathrm{~mm}$. The interannual variation of the rainfall is large, and the distribution is uneven during the year, mainly in summer (July-October), accounting for more than $60 \%$ of the annual rainfall. In winter (December-February), the rainfall is scarce, accounting for about $4 \%$ of the annual rainfall (Figure 1).

\subsection{Data Sets}

In this study, meteorological data from 22 national meteorological stations, provided by the National Meteorological Information Centre of China (NMIC) (https:/ /www.nmic.cn/), including the daily average/maximum/minimum temperature, relative humidity, sunshine duration, wind speed, and precipitation during 1970-2018, were used in this study to estimate the $E T_{\mathrm{a}}$ in the WRB. These data were verified by the NMIC before being issued. Detailed information about these stations and datas are given in Tables 1 and 2. The division of seasons is based on the meteorological weather seasons-that is, spring runs from March 
to May, summer from June to August, autumn from September to November, and winter from December to February of the following year.

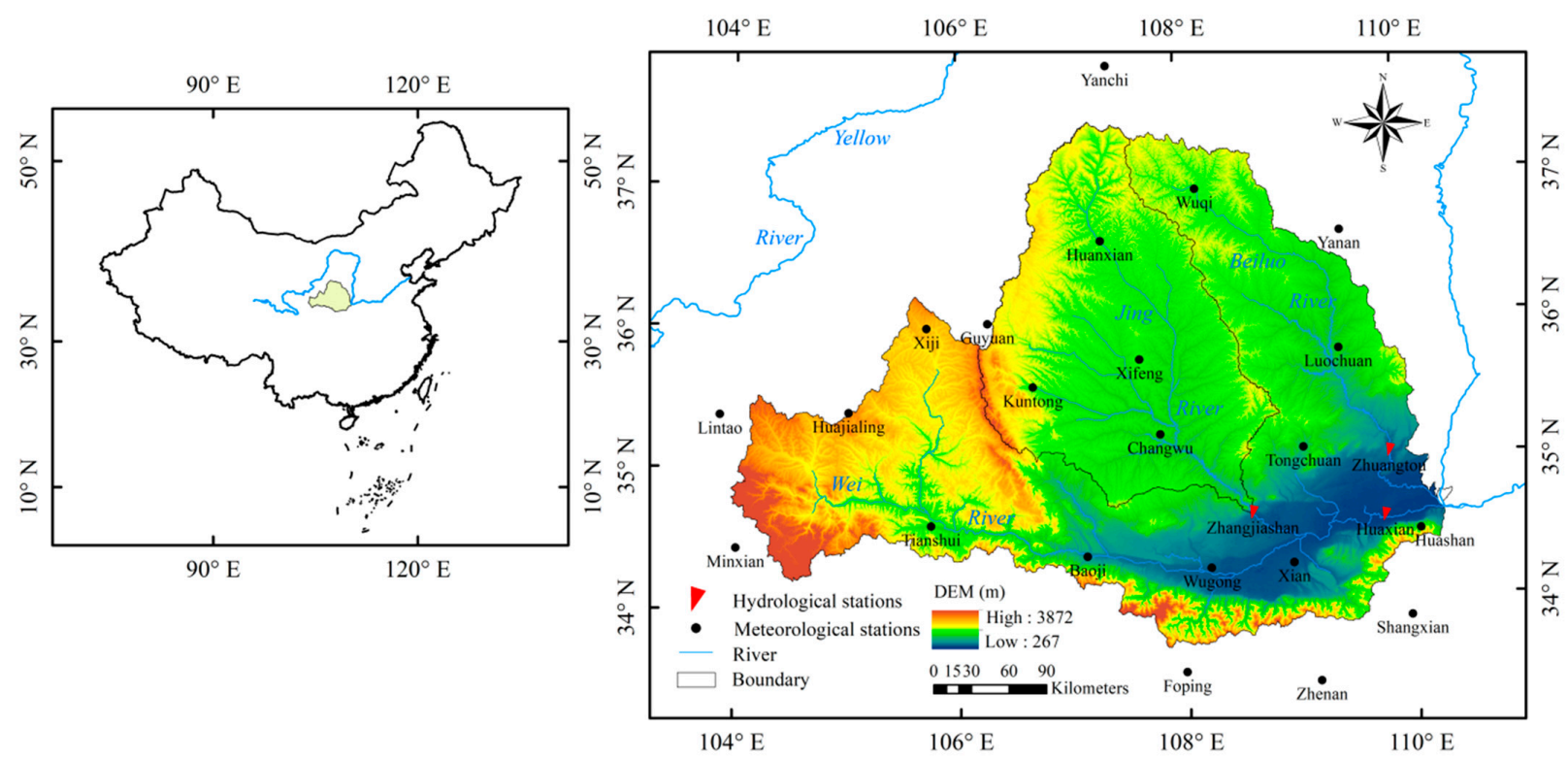

Figure 1. Location of the Weihe River Basin.

Table 1. Information for the National Meteorological Observatory Stations used in this study.

\begin{tabular}{|c|c|c|c|c|c|c|}
\hline $\begin{array}{c}\text { Sub } \\
\text { Basins }\end{array}$ & Station Number & $\begin{array}{l}\text { Station } \\
\text { Name }\end{array}$ & $\begin{array}{c}\text { Longitude } \\
\left({ }^{\circ} \mathrm{E}\right)\end{array}$ & $\begin{array}{l}\text { Latitude } \\
\left({ }^{\circ} \mathrm{N}\right)\end{array}$ & $\begin{array}{l}\text { Altitude } \\
\text { (m) }\end{array}$ & Catchment Area $\left(\mathrm{km}^{2}\right)$ \\
\hline \multirow{12}{*}{ Wei River } & 52986 & Lintao & 35.37 & 103.87 & 1886.6 & 0.16 \\
\hline & 52996 & Huajialing & 35.38 & 105.02 & 2450.6 & 0.72 \\
\hline & 56093 & Minxian & 34.43 & 104.02 & 2314.6 & 0.38 \\
\hline & 57143 & Shangxian & 33.87 & 109.97 & 742.2 & 0.08 \\
\hline & 57134 & Foping & 33.52 & 107.98 & 1791.8 & 0.11 \\
\hline & 57144 & Zhenan & 33.43 & 109.15 & 985.6 & 0.01 \\
\hline & 57006 & Tianshui & 34.58 & 105.75 & 1141.7 & 0.93 \\
\hline & 57036 & Xian & 34.27 & 108.95 & 410.0 & 0.72 \\
\hline & 57016 & Baoji & 34.35 & 107.13 & 612.4 & 0.85 \\
\hline & 53903 & Xiji & 35.97 & 105.72 & 1901.3 & 0.42 \\
\hline & 57034 & Wugong & 34.25 & 108.22 & 505.4 & 0.79 \\
\hline & 57046 & Huashan & 34.48 & 110.08 & 2064.9 & 0.51 \\
\hline \multirow{6}{*}{ Jing River } & 53821 & Huanxian & 36.57 & 107.30 & 1543.6 & 1.09 \\
\hline & 53923 & Xifeng & 35.73 & 107.63 & 1421.9 & 0.93 \\
\hline & 53929 & Changwu & 35.20 & 107.80 & 1206.3 & 0.92 \\
\hline & 53915 & Kuntong & 35.55 & 106.67 & 1346.6 & 0.99 \\
\hline & 53723 & Yanchi & 37.80 & 107.38 & 1347.8 & 0.10 \\
\hline & 53817 & Guyuan & 36.00 & 106.27 & 1753.2 & 0.34 \\
\hline \multirow{5}{*}{ Beiluo River } & 53738 & Wuqi & 36.92 & 108.17 & 1331.4 & 1.05 \\
\hline & 53845 & Yanan & 36.60 & 109.47 & 957.1 & 0.28 \\
\hline & 53942 & Luochuan & 35.77 & 109.42 & 1158.3 & 1.02 \\
\hline & 53947 & Tongchuan & 35.08 & 109.07 & 978.9 & 1.00 \\
\hline & 57046 & Huashan & 34.48 & 110.08 & 2064.9 & 0.51 \\
\hline
\end{tabular}

The hydrological data in this study include the annual streamflow during 19702018 from three hydrological stations provided by the Yellow River Water Resources Commission. The Huaxian station belongs to the main stream of Wei River, the Zhuangtou station belongs to the Beiluo River, and the Zhangjiashan station belongs to the Jing River. Detailed information on the hydrological stations is shown in Table 3. 
Table 2. Characteristics of meteorological and hydrological data in Wei River Basin.

\begin{tabular}{|c|c|c|c|c|c|c|c|c|}
\hline \multirow{2}{*}{ Decades } & \multicolumn{3}{|c|}{ Streamflow $\left(10^{8} \mathrm{~m}^{3}\right)$} & \multirow{2}{*}{$\begin{array}{l}\text { Precipitation } \\
(\mathrm{mm})\end{array}$} & \multirow{2}{*}{$\begin{array}{l}\text { Wind } \\
\text { Speed } \\
(\mathrm{m} / \mathrm{s})\end{array}$} & \multirow{2}{*}{$\begin{array}{c}\text { Average } \\
\text { Temperature } \\
\left({ }^{\circ} \mathrm{C}\right)\end{array}$} & \multirow{2}{*}{$\begin{array}{l}\text { Relative } \\
\text { Humidity }\end{array}$} & \multirow{2}{*}{$\begin{array}{c}\text { Sunshine } \\
\text { Duration } \\
\text { (h) }\end{array}$} \\
\hline & Huaxian & Zhuangtou & Zhangjiashan & & & & & \\
\hline 1970-1979 & 59.41 & 6.08 & 17.43 & 541.78 & 2.22 & 9.79 & 64.75 & 6.38 \\
\hline 1980-1989 & 79.13 & 7.39 & 17.02 & 558.79 & 1.94 & 9.75 & 65.47 & 5.83 \\
\hline 1990-1999 & 43.79 & 7.11 & 14.02 & 506.45 & 1.99 & 10.44 & 64.42 & 6.20 \\
\hline 2000-2010 & 45.04 & 5.01 & 9.28 & 526.77 & 1.88 & 10.92 & 63.75 & 6.23 \\
\hline 2010-2018 & 55.04 & 5.78 & 11.38 & 573.34 & 1.94 & 11.06 & 63.62 & 6.03 \\
\hline Mean & 56.51 & 6.29 & 13.87 & 540.78 & 2.22 & 9.79 & 64.75 & 6.38 \\
\hline \multirow{2}{*}{ Max } & 131.00 & 13.09 & 26.05 & 760.97 & 2.36 & 11.69 & 70.79 & 6.62 \\
\hline & (1983) & (1988) & (1975) & (2003) & (1970) & (2013) & (1989) & (1979) \\
\hline \multirow{2}{*}{ Min } & 16.83 & 3.09 & 4.51 & 369.49 & 1.78 & 9.04 & 59.38 & 5.13 \\
\hline & (1997) & (1973) & (2000) & (1997) & (2002) & (1984) & (1995) & (1989) \\
\hline SD & 25.92 & 2.44 & 5.39 & 82.30 & 0.14 & 0.69 & 2.21 & 0.34 \\
\hline
\end{tabular}

SD: Standard Deviation.

The hydrological data in this study include the annual streamflow during 1970-2018 from three hydrological stations provided by the Yellow River Water Resources Commission. The Huaxian station belongs to the main stream of Wei River, the Zhuangtou station belongs to the Beiluo River, and the Zhangjiashan station belongs to the Jing River. Detailed information on the hydrological stations is shown in Table 3.

Table 3. Basic information of the hydrological station in the study area.

\begin{tabular}{ccccc}
\hline $\begin{array}{c}\text { Hydrological } \\
\text { Stations }\end{array}$ & Sub-Basins & Longitude $\left({ }^{\circ} \mathbf{E}\right)$ & Latitude $\left({ }^{\circ} \mathbf{N}\right)$ & $\begin{array}{c}\text { Catchment Area } \\
\left.\mathbf{( k m}^{\mathbf{2}}\right)\end{array}$ \\
\hline Huaxian & Wei River & $34^{\circ} 35^{\prime}$ & $109^{\circ} 46^{\prime}$ & 106,500 \\
Zhuangtou & Beiluo River & $35^{\circ} 02^{\prime}$ & $109^{\circ} 50^{\prime}$ & 25,600 \\
Zhangjiashan & Jing River & $34^{\circ} 38^{\prime}$ & $108^{\circ} 36^{\prime}$ & 43,200 \\
\hline
\end{tabular}

\section{Methodology}

\subsection{Evapotranspiration Estimation}

Based on the complementary hypothesis proposed by Bouchet in 1963, Brutsaert and Stricker [47] provided a conceptual model based on the hypothetical non-advective evaporative power of the air, where the excess power in $E T_{p}$ is equal to the deficit of power in $\mathrm{ET}_{\mathrm{a}}$. The evapotranspiration under this condition is defined as wet environment evapotranspiration $\left(E T_{w}\right)$, which provides the complementary relationship between $E T_{\mathrm{a}}$ and $E T_{p}$ in Equation (1). This relationship provides an index of the aridity of the atmosphere in a given region. Therefore, this approach is referred to herein as the "Advection-Aridity" (AA) model, which is applied to calculate the $E T_{\mathrm{a}}$ in the basin:

$$
E T_{\mathrm{a}}=E T_{p}=E T_{\mathrm{w}}
$$

This equation can be used to calculate the annual, monthly [48], and daily $E T_{\mathrm{a}}$ [47], as well as the $E T_{\mathrm{a}}$ for shorter time steps. For example, Parlange and Katul reported changes in $E T_{\mathrm{a}}$ over 20 min time steps [49]. The $E T_{p}$ is calculated by the following equation originally proposed by Penman [50] for a free water surface:

$$
E T_{p}=\frac{\Delta}{\Delta+\gamma} R n+\frac{\gamma}{\Delta+\gamma} E_{a}
$$

where $\Delta$ is the slope of the saturation vapor pressure curve of the air temperature calculated using the mean air temperature, which is an important parameter for describing 
vaporization and used in the equations for calculating the $E T_{p}$ from climatic data. $\gamma$ is the psychometric constant and kept constant for each location, given by

$$
\gamma=\frac{\mathrm{c}_{p} P}{\varepsilon \lambda}=0.665 \times 10^{-3} P
$$

where $P$ is the atmospheric pressure, $R n$ is the net radiation near the surface expressed as the equivalent vaporization rate, which is the difference between the incoming net shortwave radiation and the outgoing net longwave radiation. $E_{a}$ is the drying power of the air, which, in general, can be written as

$$
E_{\mathrm{a}}=f(u)\left(e_{a}^{*}-e a\right)
$$

where $e_{a}^{*}$, ea are the vapor pressure at the evaporating surface and the vapor pressure in the atmosphere above, respectively; $f(u)$ is a function of the horizontal wind velocity; and $u_{r}$ is the wind speed at a height of $r$ meters above the ground surface. The data of the wind speed measured by the China Meteorological Observatory stations are generally taken at a height of $10 \mathrm{~m}\left(U_{10}\right)$, which needs to be converted into a wind speed at a height of $2 \mathrm{~m}$, which can be described as [50]

$$
f(u)=0.35\left(1+0.54 U_{10}\right)
$$

In Equation (1), Morton (1976) proposed calculating the wet environment evapotranspiration $\left(E T_{w}\right)$ with the Priestley-Taylor formula [51], where $\alpha$ is the Priestley-Taylor evapotranspiration coefficient, the value of $\alpha$ depends on the surface vegetation coverage and regional micro-meteorological conditions, and $\alpha$ has a highly nonlinear relationship with soil moisture content, as well as significant temporal and spatial variability. The value ranges from 0.72 in the forest environment to 1.57 under strong advection conditions. Therefore, $\alpha$ generally adopts adjusted values in different areas:

$$
E T_{w}=\alpha \frac{\Delta\left(R_{n}-G\right)}{\Delta+\gamma}
$$

by combining Equations (2) and (5), $E T_{\mathrm{a}}$ can be written as

$$
E T_{a}=(2 \alpha-1) \frac{\Delta}{\Delta+\gamma}\left(R_{n}-G\right)-\frac{\gamma}{\Delta+\gamma} E_{a}
$$

Next, we calibrate $\alpha$ in the AA model according to the closed basin water balance formula and then calculate the annual actual evapotranspiration $\left(E T_{\mathrm{a}}\right)$ of the entire basin as

$$
E T_{a}=P-R-\Delta S
$$

where $P, R$ are the annual precipitation, the net stream flow at the basin outlet, this can be calculated through the outlet runoff of three control hydrological stations in this basin divided by the area controlled by the stations (catchment areas), and $\Delta S$ is the water storage changes in a catchment, respectively. Here, the change in water storage is negligible in a given water year. Considering that $\alpha$ has the characteristics of time and spatial variation, the different sub-areas are calibrated separately. The values of $\alpha$ were determined by the minimum relative error between the multiyear average $E T_{\mathrm{a}}$ estimated by the $A A$ model and the multiyear average $E T_{\mathrm{a}}$ calculated by the water balance method. The relative error of the parameter calibration can be expressed as:

$$
\mu=\frac{E T^{W B}-E T_{a}^{A A}}{E T^{W B}} \times 100 \%
$$

where $E T^{W B}$ is the actual multi-year average evapotranspiration calculated by the water balance method, and $E T_{a}^{A A}$ is the actual multi-year average evapotranspiration calcu- 
lated by the $A A$ model. Here, 1970-1994 is the calibration period, and 1995-2018 is the verification period.

The calculated $E T_{\mathrm{a}}$ is analyzed in both time and space. In the spatial analysis, the interpolation method was used to realize the conversion of point data to area data of meteorological factors. The Kriging interpolation method was applied in this study since the uneven distribution of meteorological stations. Compared with inverse distance weighted and spline methods, Kriging is mainly used for the interpolation analysis of uneven points, and the ordinary Kriging interpolation method is the most commonly used method in geoscience statistics, and also has more applications in the spatial analysis of meteorological factors.

\subsection{Trend Detection}

Non-parametric Mann-Kendall rank correlation tests were used to detect the trend changes of $E T_{\mathrm{a}}[52,53]$. This method does not require the data to have the characteristics of a normal distribution. Instead, it requires the sequence to be random and independent, so the probability distribution is equivalent and not disturbed by a few outliers. A positive value of $Z$ indicates an upward trend, while a negative $Z$ value indicates a downward trend. This can relatively objectively determine the trend of long-term sequence data changes and is widely used in hydrology $[54,55]$.

\subsection{Sensitivity Analysis}

The sensitivity coefficient of $E T_{\mathrm{a}}$ is an important index used to measure the impact of climate factors, such as the mean temperature $\left(T_{\text {mean }}\right)$, wind speed $\left(U_{2}\right)$, solar radiation $\left(R_{S}\right)$, and actual vapor pressure (ea), on $E T_{\mathrm{a}}$. Different variables in the Penman-Monteith model have different meanings, so the sensitivity coefficient can be used to make each factor dimensionless and thereby compare the relationship between different climatic factors. To understand the influence of different factors on $E T_{a}$, the dimensionless sensitivity coefficient defined by the dimensionless partial derivative with respect to the independent factors is used in this study. McCuen (1974) and Beven (1979) transformed the partial derivative into a non-dimensional form to determine the sensitivity of the variables:

$$
S V_{\mathrm{i}}=\lim _{\Delta V_{i \rightarrow 0}}\left(\frac{\Delta E T_{a} / E T_{a}}{\Delta V_{i} / V_{i}}\right)=\frac{\partial E T_{a}}{\partial V_{i}} \times \frac{V_{i}}{E T_{a}}
$$

where $S V_{i}$ is the sensitivity coefficient, and $V_{i}$ is the $i$ th variable. The sensitivity coefficient represents the variable of $E T_{\mathrm{a}}$ caused by changes in meteorological factors. A positive value of $S V_{i}$ indicates that $E T_{\mathrm{a}}$ increases with increases in the meteorological factor, and vice versa. This method has been widely used in evapotranspiration studies $[22,23,32,54]$.

\subsection{Trend Attribution}

The contribution amount of each meteorological variable to evapotranspiration can be expressed as the partial derivative of $E T_{\mathrm{a}}$ to the factor multiplied by the slope of the factor change and can be calculated by the following total differential equation [32]:

$$
\frac{d E T_{a}}{d t}=\sum \frac{\partial E T_{a}}{\partial x_{i}} \frac{d x_{i}}{d t}=\sum f_{i}^{\prime} \frac{d x_{i}}{d t}
$$

If we let $T R_{y}=d y / d t$ and $T R_{i}=d x_{i} / d t$ be the long-term trends in $y$ and $x_{i}$, then Equation (10) can be rewritten as

$$
T R_{y}=\sum f_{i}^{\prime} T R_{i}=\sum C\left(x_{i}\right)
$$

If $T R_{y}$ and $T R_{i}$ are estimated as the slope of the linear regression for $y$ and $x_{i}$ against time $t, C\left(x_{i}\right)$ can then be estimated as the contribution of $x_{i}$ to the long-term trend in $y$, which is exactly the product of the partial derivative and long-term trend in $x_{i}$ :

$$
\frac{d E T_{a}}{d t}=\frac{\partial E T_{a}}{\partial U_{2}} \frac{d U_{2}}{d t}+\frac{\partial E T_{a}}{\partial R_{\mathrm{s}}} \frac{d \mathrm{Rs}}{d t}+\frac{\partial E T_{a}}{\partial T_{\text {mean }}} \frac{d T_{\text {mean }}}{d t}+\frac{\partial E T_{a}}{\partial e_{a}} \frac{d e_{a}}{d t}
$$


This can be simplified to

$$
L\left(E T_{a}\right)=C\left(U_{2}\right)+C\left(R_{s}\right)+C\left(T_{\text {mean }}\right)+C\left(e_{a}\right)
$$

where the left side of the equation represents the change in $E T_{\mathrm{a}}$ during the study period, and the right side is the sum of the contributions of the four meteorological factors. Here, $C\left(U_{2}\right), C(R n), C\left(T_{\text {mean }}\right)$, and $C\left(e_{a}\right)$ represent the contributions of $U_{2}, R s, T_{\text {mean }}$, and $e_{a}$ contributed to the long-term $\mathrm{ET}_{\mathrm{a}}$ changes, respectively. If the contribution value is positive, the $E T_{\mathrm{a}}$ increased with the long-term changes of the meteorological variables, and if the contribution value is negative, then the result is the opposite.

In addition, the contribution rate of a meteorological factor to the long-term trend of $E T_{\mathrm{a}}$ is

$$
P(x)=\frac{c(\mathrm{x})}{c\left(T_{\text {mean }}\right)+c\left(R_{n}\right)+c\left(e_{a}\right)+c\left(U_{2}\right)} \times 100 \%
$$

where $P(x)$ is the contribution rate of a meteorological factor to the long-term trend of $E T_{\mathrm{a}}$.

\section{Results and Discussion}

The hydrological and precipitation data were available from 1970 to 2018 for the whole basin, these data were used for calibration only and the results listed in Table 4 . The calibration period was selected from 1970 to 1994, and the validation period was from 1995 to 2018 for the Wei River basin. Considering that the model parameters varied spatially, the Wei River Basin was divided into three larger sub-areas, the Wei River, Jing River, and Beiluo River, to calibrate the model parameters, respectively. The value of $\alpha$ ranged from 0.5 to 1.5 , with a step size of 0.01 , taking the $\alpha$ when the relative error between the multi-year $E T_{\mathrm{a}}$ calculated by the $A A$ model and the multi-year $E T_{\mathrm{a}}$ calculated by the water balance reached the minimum. The $A A$ model calibration results are shown in Table 3 . The values of $\alpha$ in the Wei River, Jing River, and Beiluo River are 0.93, 0.88, and 0.96, respectively. Compared with the calibration period, the relative error of $E T_{\mathrm{a}}$ in the validation period ranged within $\pm 10 \%$ in three sub-areas. Meanwhile, the absolute errors during calibration period were 26.04 in Jing River, -14.59 in Beiluo River, -2 in Wei River, the absolute error in the validation period ranged with $-5.36--0.46$ in three sub-basins. Consequently, the $E T_{\mathrm{a}}$ estimated by the $A A$ model was reasonable.

\begin{tabular}{|c|c|c|c|c|c|c|c|c|c|c|c|}
\hline \multirow[t]{2}{*}{ Sub-Areas } & \multirow{2}{*}{$\begin{array}{l}\text { Hydrological } \\
\text { Station }\end{array}$} & \multirow{2}{*}{$\begin{array}{l}\text { Area } \\
\left(\mathrm{km}^{2}\right)\end{array}$} & \multirow[t]{2}{*}{$\alpha$} & \multicolumn{6}{|c|}{$\begin{array}{l}\text { Calibration Period (1970-1997) } \\
\text { Annual Mean } E T_{\mathrm{a}}(\mathrm{mm})\end{array}$} & \multicolumn{2}{|c|}{$\begin{array}{c}\text { Validation Period } \\
\quad(1998-2018) \\
\text { Annual Mean } E T_{\mathrm{a}}(\mathrm{mm})\end{array}$} \\
\hline & & & & $\begin{array}{c}\text { Water } \\
\text { Balance }\end{array}$ & $\begin{array}{c}\text { AA } \\
\text { Model }\end{array}$ & $\begin{array}{l}\text { Absolute } \\
\text { Error }\end{array}$ & $\begin{array}{l}\text { Relative } \\
\text { Error (\%) }\end{array}$ & $\begin{array}{c}\text { Water } \\
\text { Balance }\end{array}$ & $\begin{array}{c}\text { AA } \\
\text { Model }\end{array}$ & $\begin{array}{l}\text { Absolute } \\
\text { Error }\end{array}$ & $\begin{array}{l}\text { Relative } \\
\text { Error (\%) }\end{array}$ \\
\hline Wei River & Huaxian & 63,300 & 0.93 & 525.83 & 527.84 & -2.00 & -3.1 & 526.33 & 528.97 & -2.46 & -2.5 \\
\hline Jing River & Zhangjiashan & 43,200 & 0.88 & 489.67 & 463.63 & 26.04 & 2.4 & 450.25 & 450.89 & -0.64 & -4.1 \\
\hline Beiluo River & Zhuangtou & 25,600 & 0.96 & 559.18 & 573.77 & -14.59 & -4.4 & 545.78 & 551.41 & -5.63 & -4.3 \\
\hline
\end{tabular}

Table 4. The Advection-Aridity (AA) model calibration results in the Weihe River Basin.

\subsection{Temporal Change}

The temporal changes in annual and seasonal $E T_{\mathrm{a}}$ from 1970-2018 are given in Figure 2a. The annual average $E T_{\mathrm{a}}$ in the WRB was $522.73 \mathrm{~mm}$, with an insignificant increasing trend from 1970 to 2018. The averages of $E T_{\mathrm{a}}$ for spring, summer, autumn, and winter were $166.32 \mathrm{~mm}, 226.1 \mathrm{~mm}, 83.87 \mathrm{~mm}$, and $34.77 \mathrm{~mm}$, respectively, accounting for $31.82 \%, 43.25 \%$, $16.04 \%$, and $6.65 \%$ of the annual $E T_{\mathrm{a}}$. The seasonal $E T_{\mathrm{a}}$ also showed an insignificant increasing trend over the study period, except for the $E T_{\mathrm{a}}$ in autumn, which showed an insignificant decreasing trend. The inter-annual variation of $E T_{\mathrm{a}}$ showed that the $E T_{\mathrm{a}}$ increased from January to July but decreased from August to December, with the largest $E T_{\mathrm{a}}$ from April to September (Figure 2b). 

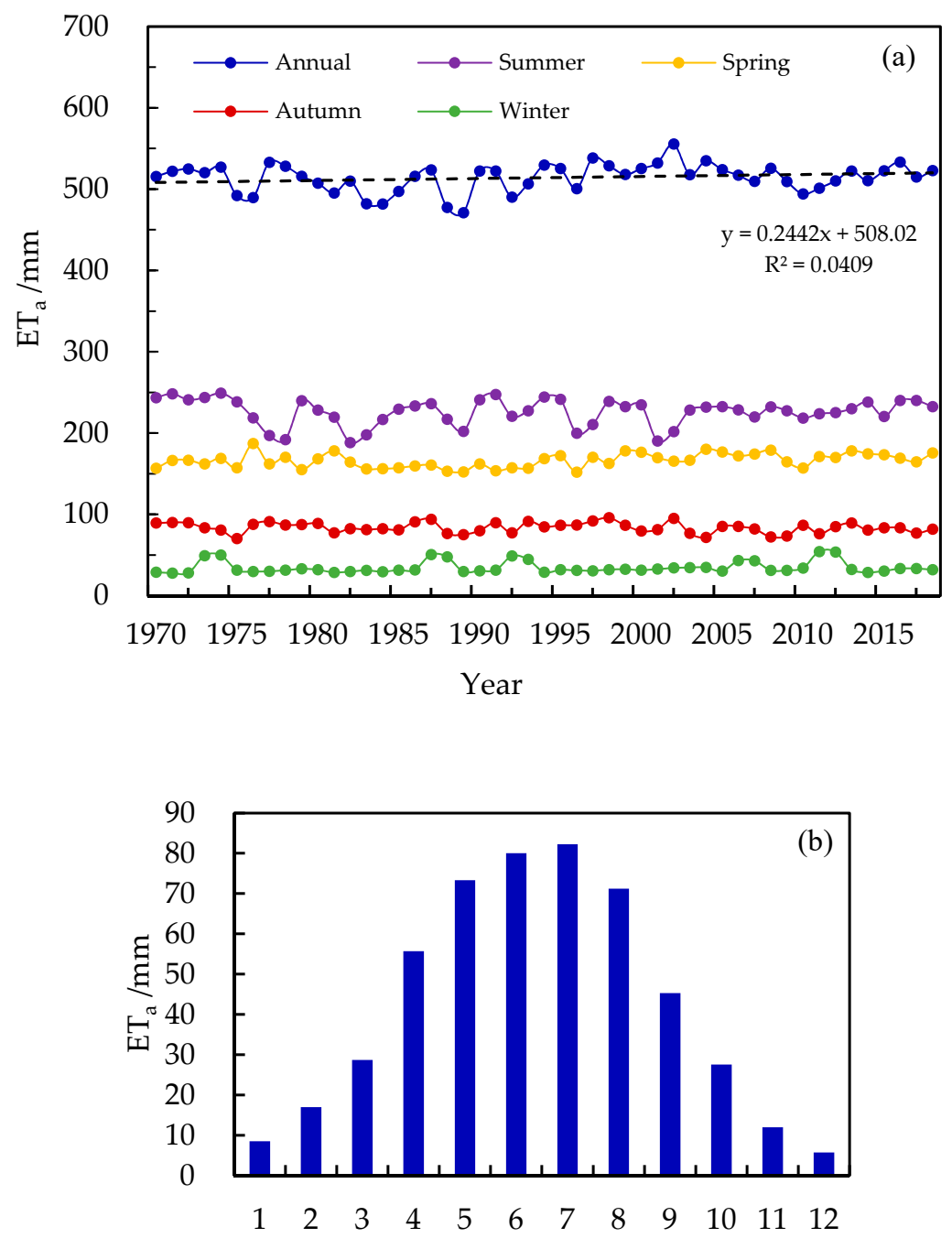

Month

Figure 2. The variation of the annual, seasonal and monthly $E T_{\mathrm{a}}$ in the Weihe River Basin from 1970 to 2018. (a): Annual and seasonal; (b): Monthly.

\subsection{Spatial Distribution of Seasonal and Annual $E T_{a}$}

The spatial distribution of seasonal and annual $E T_{\mathrm{a}}$ in the WRB is shown in Figure 3, based on data interpolated by the Ordinary Kriging interpolation method (a method widely used in geoscience statistics [52]) from 22 meteorological stations during 1970-2018. The mean annual $E T_{\mathrm{a}}$ ranged from $436.8 \mathrm{~mm}$ to $601.8 \mathrm{~mm}$, with the high annual $E T_{\mathrm{a}}$ values distributed in the eastern part of the whole basin and the southern part of the Wei River and low annual $E T_{\mathrm{a}}$ values mostly found in the western and central areas of the WRB. The $E T_{\mathrm{a}}$ decreased from southeast to northwest in the WRB. The distribution patterns of seasonal $E T_{\mathrm{a}}$ were similar to the annual patterns, which were roughly consistent in different regions. In summer and autumn, the distribution of $E T_{\mathrm{a}}$ was basically consistent with the spatial changes in the annual $E T_{\mathrm{a}}$ values. In spring and winter, higher $E T_{\mathrm{a}}$ values were found in the eastern part of the whole basin, while lower $E T_{\mathrm{a}}$ was observed in the central and northwestern areas of the whole basin, decreasing from east to west. The annual, summer, and autumn distributions of $E T_{\mathrm{a}}$ seem to be related to the elevation change of the basin. The $E T_{\mathrm{a}}$ value was found to be higher at lower altitudes and lower at higher altitudes. 

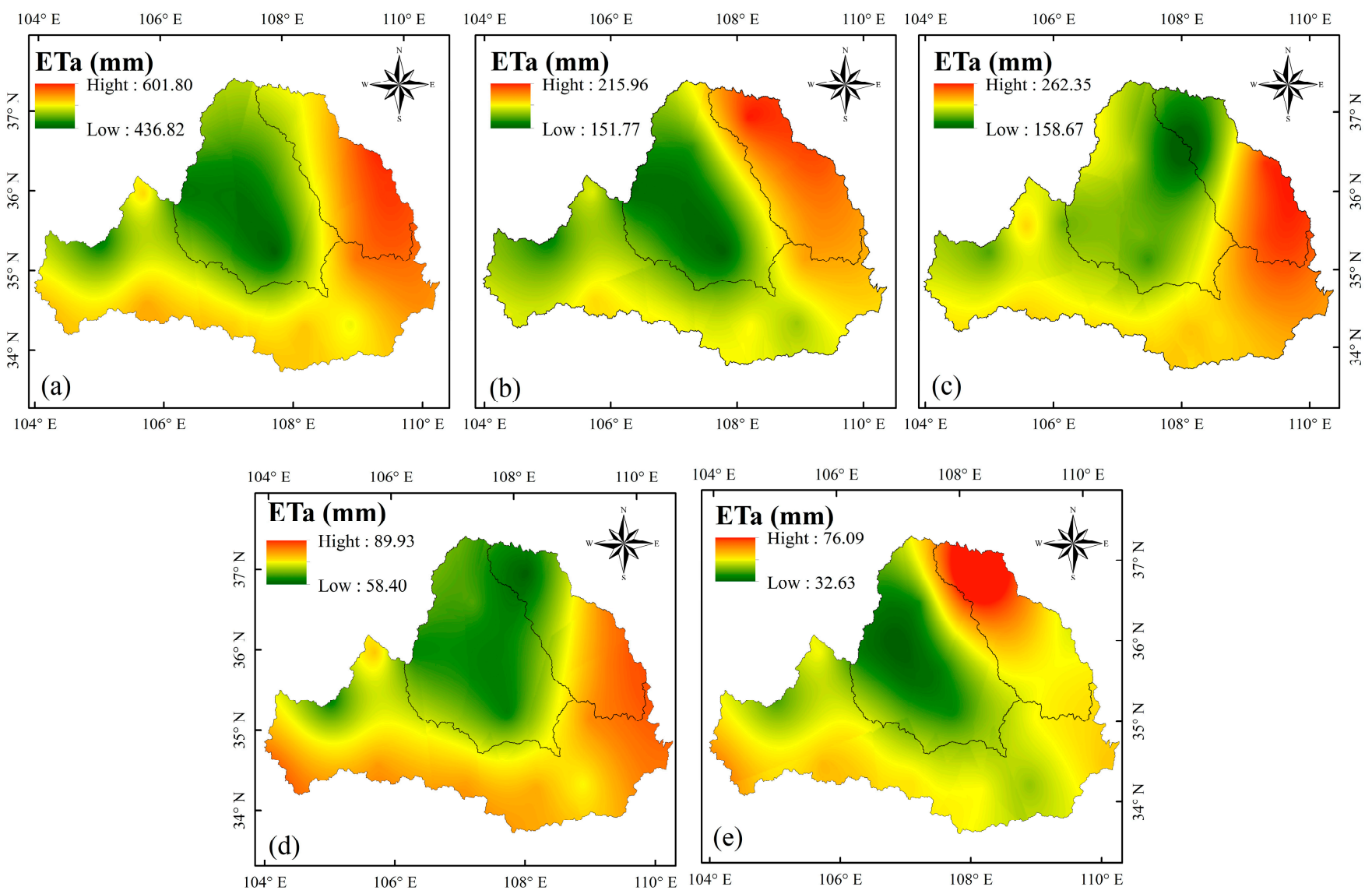

Figure 3. Spatial distribution of annual and seasonal $E T_{\mathrm{a}}$ in the Weihe River Basin ((a): Annual, (b): Spring, (c): Summer, (d): Autumn, (e): Winter).

In spring, summer, and autumn, $E T_{\mathrm{a}}$ was higher in the east and south of the basin and lower in the central and western regions. In the east of the basin is the Beiluo River, which was the first demonstration site for the implementation of the Grain for Green program in China. This area has high forest coverage, and its interception evaporation and vegetation transpiration increase with the increasing of large-scale vegetation restoration. The south of the basin near the north of the Qinling Mountains belongs to a warm temperate semihumid climate zone. There are a large number of warm temperate deciduous broad-leaved forests in the area with good vegetation coverage. In addition, the Guanzhong Plain lies in the southern part of the basin, which is one of the major grain-producing areas in Shaanxi province; the farmland irrigation also leads to an increase of $E T_{\mathrm{a}}$. Therefore, the increase in cultivated land and woodland have enhanced the $E T_{\mathrm{a}}$ in the east and south of the basin. Some studies have shown that vegetation restoration resulted in an increase of the $E T_{\mathrm{a}}$ in the Loess Plateau [56]. The land type in the west and north is mainly grassland, and the evapotranspiration in grassland is less than that in woodland and cultivated land. Grassland is less disturbed by human activities than other types, so the $E T_{\mathrm{a}}$ change is relatively constant in the west and north of the basin. The decrease of $E T_{\mathrm{a}}$ in the northern part of the basin is also related to a decrease in sunshine and wind to a certain extent [57]. Compared with other seasons, the $E T_{\mathrm{a}}$ decreased in winter in the central and eastern basins, mainly due to the low temperature decreasing the vegetation transpiration and water demands in agricultural irrigation regions.

\subsection{The Trends of $E T_{a}$ Change}

The trend of $E T_{\mathrm{a}}$ tested by the Mann-Kendall method is shown in Figure 4. Here, the trend of $E T_{\mathrm{a}}$ for the WRB is characterized by complicated spatial variability. The annual $E T_{\mathrm{a}}$ increased at 17 stations, with six (27\%) stations significant at a $95 \%$ confidence level 
(the values of $M K$ test over the 2.76). The annual $E T_{\mathrm{a}}$ decreased at five stations, mainly distributed in the southern part of the basin. In spring, the $E T_{\mathrm{a}}$ increased significantly at 22 stations, with 11 of those stations dominated by significant increasing trends at a $95 \%$ confidence level. In summer, the $E T_{\mathrm{a}}$ of the 16 stations presented a decreasing trend, but most of them presented no obvious significance. Most stations in the autumn presented an increasing trend, mainly distributed in the upper area of Jing River and the northern part of the whole basin, accounting for $59 \%$ of all stations, but the significance was not very high. For the winter, the $E T_{\mathrm{a}}$ increased at 20 stations (10 of which were statistically significant at a $95 \%$ confidence level, accounting for $45.5 \%$ of all stations), whereas only two stations decreased with a low-significance confidence level.
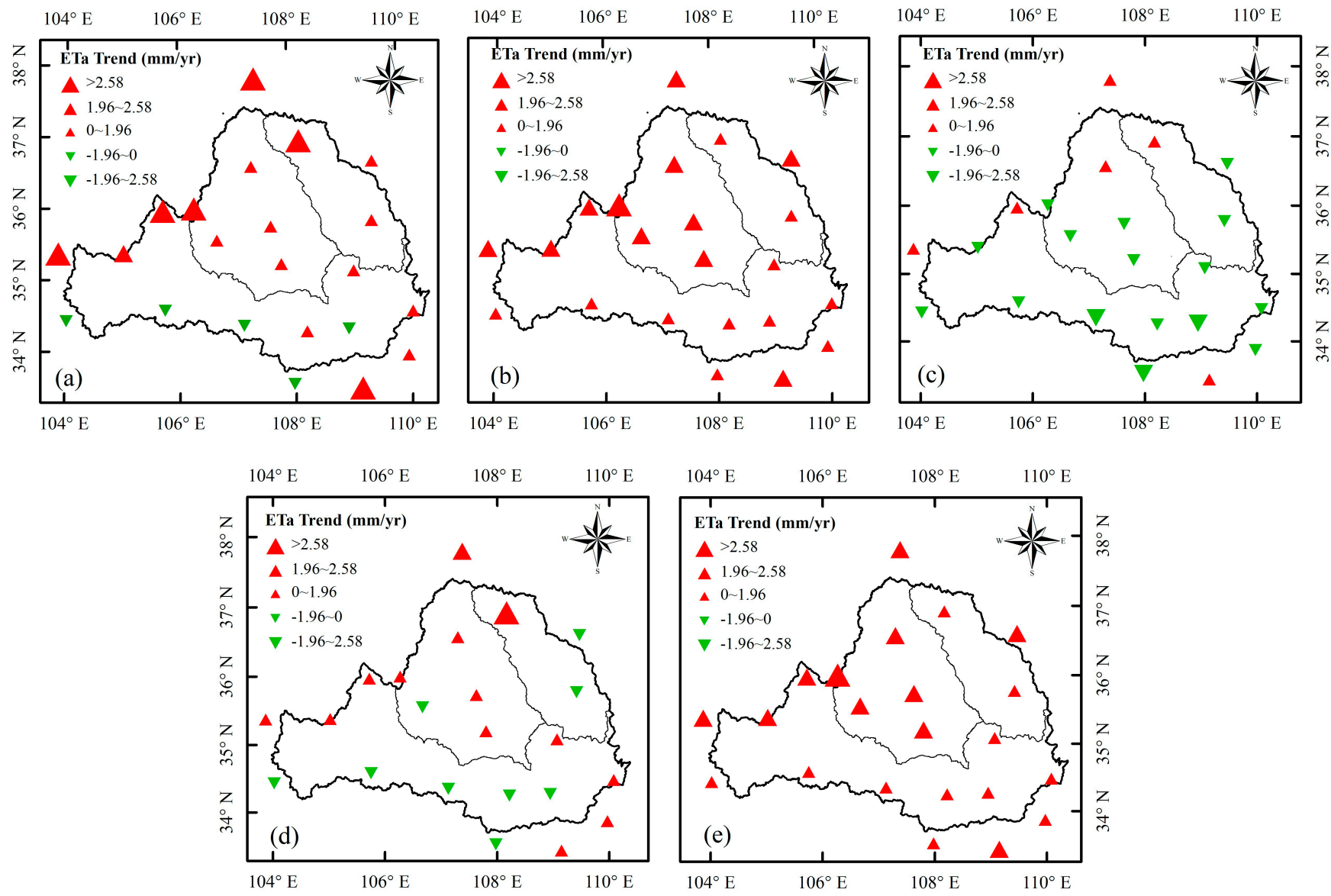

Figure 4. The values of Mann-Kendall test results of the ET $\mathrm{a}$ during 1970-2018 ((a): Annual, (b): Spring, (c): Summer, (d): Autumn, (e): Winter).

In terms of the different watersheds, the $E T_{\mathrm{a}}$ on the main stream of the Wei River mainly increased in spring and winter, the Beiluo River showed an increasing trend in other seasons (except for summer and autumn), and the Jing River showed an increasing trend in other seasons, except for summer.

\subsection{Impact Factors of $E T_{a}$}

\subsubsection{Sensitivity of the $\mathrm{ET}_{\mathrm{a}}$ to Meteorological Variables}

The average annual values of the sensitivity coefficients for the mean temperature, solar radiation, wind speed, and vapor pressure were $-0.02,0.30,0.16$, and -0.18 over the whole basin, respectively (Table 5). These results indicate that solar radiation is the most sensitive meteorological variable for $E T_{\mathrm{a}}$ changes, followed by vapor pressure, wind speed, and mean temperature in this basin. Annually, the $E T_{\mathrm{a}}$ showed a positive correlation with the mean temperature, solar radiation and wind speed and a negative correlation with the 
vapor pressure, indicating that the $E T_{\mathrm{a}}$ increases with an increase of mean temperature and vapor pressure but decreases with a decrease of solar radiation and/or wind speed. For example, when mean temperature, solar radiation, and wind speed increased by $10 \%$ and vapor pressure reduced by $10 \%, E T_{\mathrm{a}}$ will increase by $0.02 \%, 0.3 \%, 0.16 \%$, and $0.18 \%$, respectively. Seasonally, spring and winter are the most sensitive to solar radiation and wind speed, while summer and autumn are the most sensitive to solar radiation and vapor pressure. In general, both years and seasons are the most sensitive to solar radiation and the least sensitive to mean temperature. Another study also confirmed that solar radiation $[58,59]$ and relative humidity $[35,60]$ are the most sensitive factors affecting evapotranspiration changes in some regions, such as most parts of China [61,62], the Upper Heihe River Basin [63], and India [16]. Recently, Zhao (2018) [64] reported that relative humidity is the most sensitive meteorological variable for evapotranspiration changes in the north, northeast, and northwest of China, followed by wind speed, while in central, southwest, and eastern China, relative humidity is the most sensitive factor, followed by solar radiation. Fan Junliang (2016) showed that hours of sunshine is the most sensitive factor in plateau areas, while relative humidity is the most sensitive factor in temperate continental climate zones, temperate monsoon climate zones, and subtropical monsoon climate zones [65]. Therefore, the changes in evapotranspiration and sensitivity to different meteorological factors are quite different in different regions.

Table 5. The mean Sensitivity coefficients for mean temperature, solar radiation, wind speed, vapor pressure in the whole basins of Wei River Basin, which were represented as $S(T), S\left(R_{n}\right), S(U)$ and S(ea), respectively.

\begin{tabular}{cccccc}
\hline Variables & Spring & Summer & Autum & Winter & Annual \\
\hline$S(T)$ & 0.003 & 0.003 & 0.002 & -0.001 & 0.020 \\
$S\left(R_{n}\right)$ & 0.214 & 0.195 & 0.281 & 0.486 & 0.300 \\
$S(U)$ & 0.124 & 0.070 & 0.102 & 0.329 & 0.160 \\
$S(e a)$ & -0.141 & -0.111 & -0.153 & -0.324 & -0.180 \\
\hline
\end{tabular}

The monthly sensitivity coefficients of the meteorological variables showed that the sensitivity coefficients of $E T_{\mathrm{a}}$ to solar radiation and wind speed are positive, indicating that $E T_{\mathrm{a}}$ experiences an increasing trend with an increase in solar radiation and wind speed (Figure 5). The $E T_{\mathrm{a}}$ sensitivity coefficient to solar radiation is between 0.19 and 0.53 , with the maximum in December and the minimum in August. The sensitivity coefficient to wind speed is between -0.01 and 0.53 , with the maximum and minimum values in January and August, respectively. The sensitivity coefficients of $E T_{\mathrm{a}}$ to mean temperature and vapor pressure all have negative values (except for the positive temperatures in December), indicating that the $E T_{\mathrm{a}}$ decreases with an increase in mean temperature and vapor pressure during the year. The sensitivity coefficient of $E T_{\mathrm{a}}$ to mean temperature is between -0.03 and 0.02. The maximum occurs in December, and the minimum occurs in June. The sensitivity coefficient to vapor pressure is between -0.36 and 0.09 ; the maximum occurs in June, and the minimum occurs in December. In addition, the change curve for the sensitivity coefficient of $E T_{\mathrm{a}}$ to solar radiation and vapor pressure changes symmetrically.

The spatial distribution of the annual sensitivity coefficient of the $E T_{\mathrm{a}}$ in the WRB from 1970 to 2018 is shown in Figure 6. The sensitivity of $E T_{\mathrm{a}}$ to different meteorological variables has a certain zone distribution. Based on the distribution analysis of the $E T_{\mathrm{a}}$ to the mean temperature sensitivity coefficient, the sensitivity coefficient value is distributed between -0.03 and 0.02 . The high-value areas mainly occur around the Baoji station and the main stream of the Wei River, where the sensitivity coefficient values are positive, while the rest of the stations in the basin have negative values, and low-value areas are mainly distributed in the southeast of the basin. Based on the distribution analysis of the $E T_{\mathrm{a}}$ for the solar radiation sensitivity coefficient $S\left(R_{n}\right)$, the sensitivity coefficients are mainly distributed between 0.16 and 0.39 ; the high value areas are mainly distributed in the upper reaches of the Jing River, and the sensitivity coefficients of the whole basin all 
have positive values, indicating that the $E T_{\mathrm{a}}$ of the entire basin increases with an increase in solar radiation. The low-value areas are mainly distributed around Wuqi station in the upper reaches of Beiluo River, with an area smaller than the high-value area. In addition, a similar spatial distribution of sensitivity value changes can be observed for wind speed and vapor pressure, which have a coherent spatial pattern, and both show a decreasing trend from west to east. The high-value areas are mainly located in the middle east of the basin, while the low-value areas are located in the west side of the basin. The high-value areas of wind speed and vapor pressure account for nearly half of the basin's area.

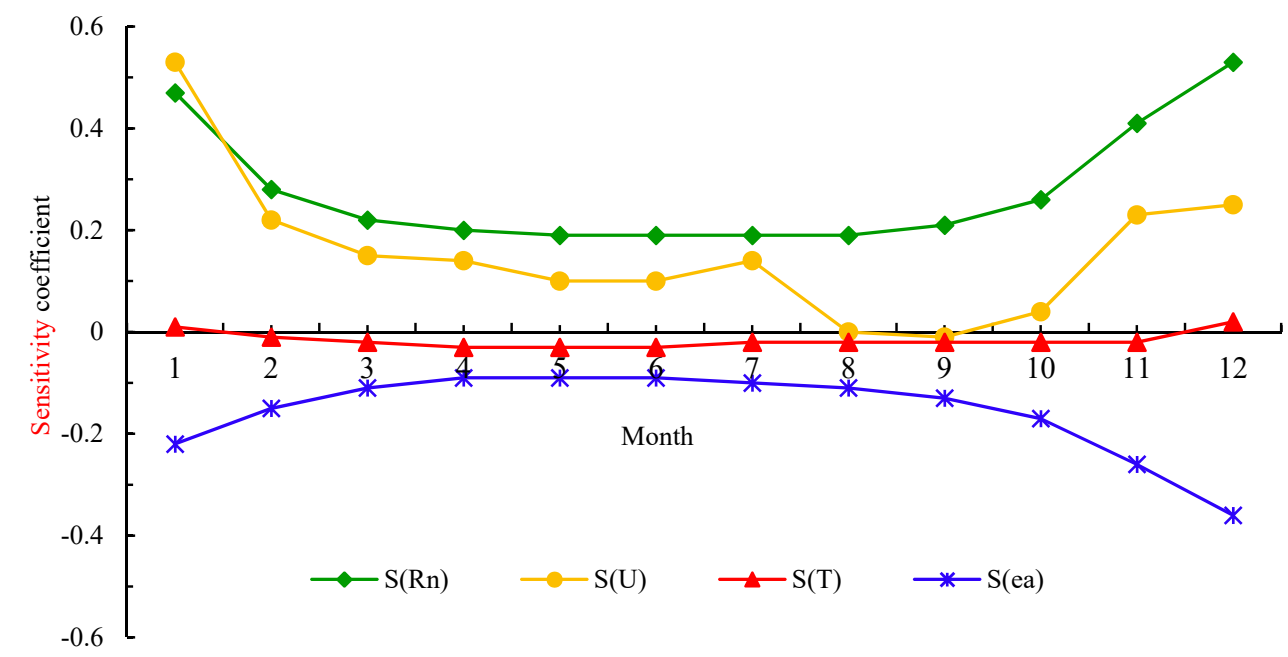

Figure 5. Variation of monthly mean sensitivity coefficient in Weihe River Basin.

\subsubsection{Contribution of the $\mathrm{ET}_{\mathrm{a}}$ to Climatic Variables}

Table 6 shows the contributions of each meteorological variable to $E T_{\mathrm{a}}$ changes. Annually, the increase in mean temperature and vapor pressure should have led to -0.0033 and $-0.0001 \mathrm{~mm} \cdot \mathrm{a}^{-1}$ decreases in $E T_{\mathrm{a}}$, respectively; however, the decreases of solar radiation and wind speed instead yielded -0.0058 and $-0.0006 \mathrm{~mm} \cdot \mathrm{a}^{-1}$ decreases in $E T_{\mathrm{a}}$. The total contribution of different meteorological variables led to a decrease of $-0.0046 \mathrm{~mm} \cdot \mathrm{a}^{-1}$ in $E T_{\mathrm{a}}$. It is thus concluded that solar radiation is the dominant factor decreasing the annual $E T_{\mathrm{a}}$. The contribution rates of mean temperature, solar radiation, wind speed, and vapor pressure to the long-term trends for annual $E T_{\mathrm{a}}$ were $2.79 \%, 12.69 \%, 12.89 \%$, and $71.64 \%$, respectively. This indicates that in the long term, solar radiation is the most crucial factor (except autumn) for $E T_{\mathrm{a}}$ changes over the WRB, followed by vapor pressure, wind speed, and mean temperature.

Seasonally, the contributions of each meteorological variable in summer and autumn (the warm season) are larger than those in spring and winter, and the total contributions of each season are negative, except for winter. The contribution of each factor in the first half of the year was greater than that in the second half of the year, indicating that the $E T_{\mathrm{a}}$ changes in the basin were mainly affected by the summer and autumn. For annual contributions, solar radiation was found to be the dominant factor affecting the seasonal contributions to $E T_{\mathrm{a}}$ in the study area, except for autumn, followed by vapor pressure, mean temperature, and wind speed. For example, in spring, the mean temperature, solar radiation, vapor pressure, and wind speed led to a $0.0024,-0.0082,0.0011$, and $-0.0104 \mathrm{~mm} \cdot \mathrm{a}^{-1}$ decrease in $E T_{\mathrm{a}}$, respectively. Wind speed, on the other hand, showed a positive effect on $E T_{\mathrm{a}}$. This effect was offset by decreases in the mean temperature, solar radiation, and vapor pressure. The combined effects of the four meteorological factors resulted in a $-0.0199 \mathrm{~mm} \cdot \mathrm{a}^{-1}$ decrease in $E T_{a}$. Based on the contribution rates of different meteorological variables to the long-term trends in seasonal and annual $E T_{\mathrm{a}}$, vapor pressure was found to be the dominant factor (except in autumn) for $E T_{\mathrm{a}}$ changes over the WRB, followed by solar radiation, wind speed, and mean temperature. 

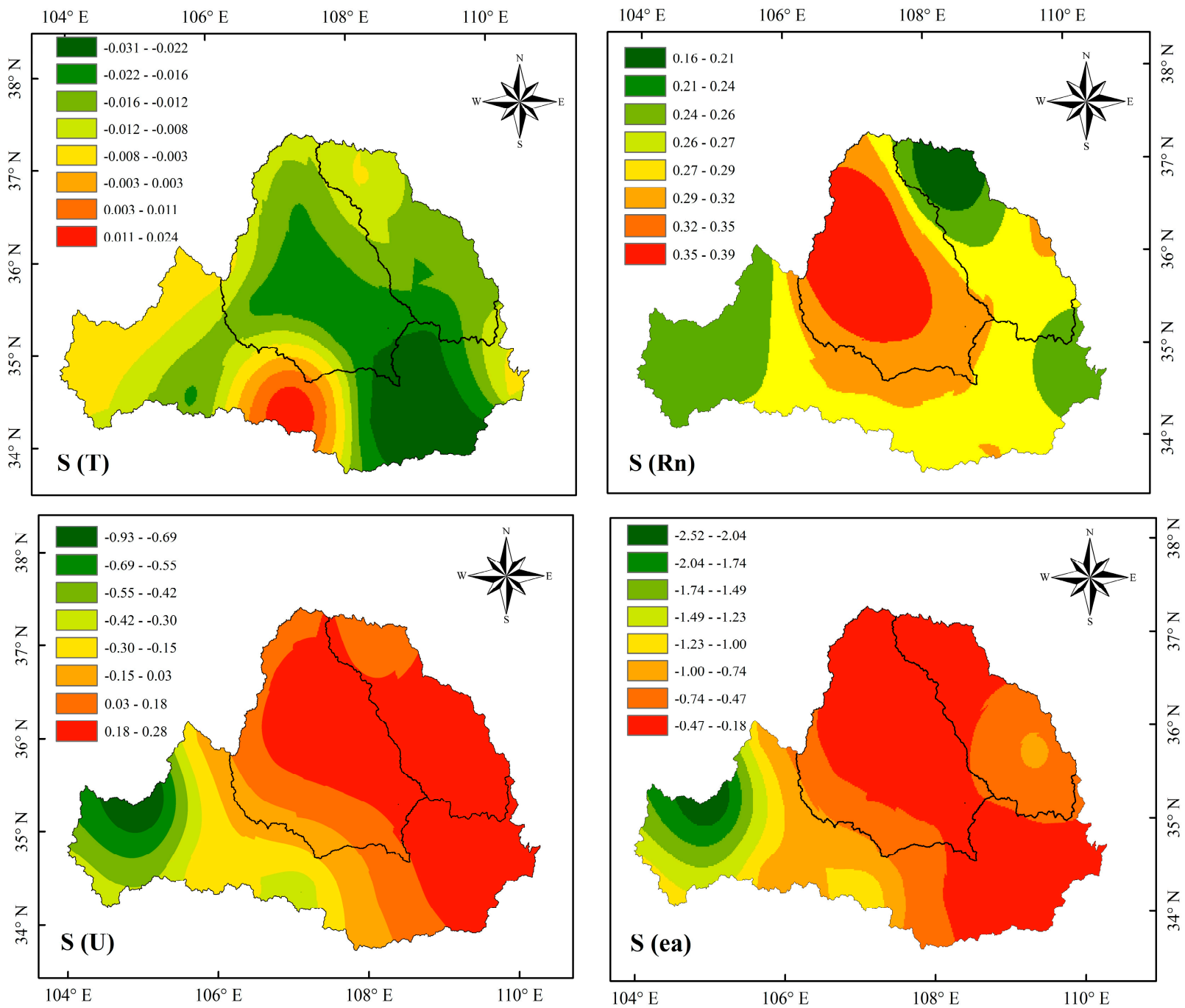

Figure 6. Spatial distribution of the mean annual sensitivity coefficients of the Weihe River Basin.

Table 6. Contributions of meteorological variables to the long-term trend in $E T_{\mathrm{a}}$.

\begin{tabular}{|c|c|c|c|c|c|}
\hline \multirow{2}{*}{ Period } & \multicolumn{5}{|c|}{ Contribution } \\
\hline & $C(T)$ & $C(R n)$ & $C\left(U_{2}\right)$ & $C(e a)$ & $C\left(E T_{a}\right)$ \\
\hline Spring & -0.0024 & -0.0082 & 0.0011 & -0.0104 & -0.0199 \\
\hline Summer & -0.0006 & 0.0099 & -0.0002 & -0.0024 & -0.0153 \\
\hline Autumn & -0.0001 & -0.0085 & -0.0002 & -0.0072 & -0.0160 \\
\hline Winter & 0.0004 & -0.0091 & -0.0001 & 0.0057 & 0.0485 \\
\hline Annual & -0.0001 & -0.0058 & -0.0006 & -0.0033 & -0.0046 \\
\hline \multirow{2}{*}{ Period } & \multicolumn{5}{|c|}{ Proportional Contribution (\%) } \\
\hline & $P(T) / \%$ & $P(R n) / \%$ & $P\left(U_{2}\right) / \%$ & $P(e a) / \%$ & $P_{\text {sum }}$ \\
\hline Spring & 12.05 & 41.16 & -5.48 & 52.28 & 100.00 \\
\hline Summer & 3.60 & -64.33 & 1.46 & 159.27 & 100.00 \\
\hline Autumn & 0.79 & 52.94 & 1.36 & 44.92 & 100.00 \\
\hline Winter & 0.90 & -18.69 & -0.21 & 118.01 & 100.00 \\
\hline Annual & 2.79 & 12.69 & 12.89 & 71.64 & 100.00 \\
\hline
\end{tabular}

Note: $C(T), C\left(R_{n}\right), C(e a)$ and $C\left(U_{2}\right)$ respectively represent the contribution of the average temperature, net solar radiation, actual water vapor pressure and wind speed to the long-term trend of $E T_{a}, C\left(E T_{a}\right)$ represents the sum of the contribution of the four meteorological factors over the years; $P(T), P\left(R_{n}\right), P(e a)$ and $P\left(U_{2}\right)$ represent the contribution rate of mean temperature, net solar radiation, actual water vapor pressure and wind speed to the long-term trend of $E T_{a}$, respectively; $P_{\text {sum }}$ are the total contribution rate of average temperature, net solar radiation, actual water vapor pressure and wind speed to the long-term trend of $E T_{\mathrm{a}}$. 
The sensitivity coefficient of $E T_{\mathrm{a}}$ to meteorological factors refers to the changes of $E T_{\mathrm{a}}$ caused by the unit changes of the meteorological variables, while the actual contributions of these variables to the changes of $E T_{\mathrm{a}}$ also depend on their own variability. Therefore, whether or not a single meteorological variable is the main factor affecting the changes in long-term $E T_{\mathrm{a}}$ depends on the combined effect of the sensitivity of this meteorological variable to $E T_{\mathrm{a}}$ and the slopes of the variable itself. For example, although vapor pressure is the second-most sensitive variable to annual $E T_{\mathrm{a}}$ changes in this region, it presents the largest impact (contribution) to $E T_{\mathrm{a}}$ changes compared to other climatic variables in spring. Generally, solar radiation is the dominant factor affecting the changes in annual $E T_{\mathrm{a}}$, followed by vapor pressure.

Overall, the change of different meteorological variables during 1970-2018 showed in Figure 7 , it can be concluded from the above analyses that the increasing vapor pressure or decreasing relative humidity is primarily responsible for the $E T_{\mathrm{a}}$ changes in the WRB. The relative humidity is mainly determined by the vapor pressure, so the relative humidity is the dominant meteorological factor that affects the $E T_{\mathrm{a}}$ in the WRB. Similarly, differences in the controlling climatic factors have also been identified in many other regions. Jung et al. (2010) [35] and Marshall (2012) [66] found that the general global average annual evapotranspiration increased from 1982 to 1997, but after the strongest El Niño phenomenon happened in 1998 the global evapotranspiration growth trend seems to have stopped, and the global average land evapotranspiration decreased. This change in evapotranspiration is mainly due to the moisture limitations in the southern hemisphere, especially the weakening of water vapor sources in Africa and Australia (Jung et al., 2010) [35]. On the other hand, this study region located in the southeast portion of the Yellow river, where the moisture introduced by the southeast monsoon from the South China sea and/or Bohai combined with topographic factors can directly influence the relative humidity [58]. Relative humidity is affected by vapor pressure, and saturated vapor pressure has a direct relationship with temperature. Therefore, increasing the temperature would lead to increasing the saturated vapor pressure, further causing a decrease in relative humidity and eventually an increase in evapotranspiration. Zhang (2011) [67] also found that relative humidity is the most sensitive factor for changes in the reference evapotranspiration in northwest China and attributed the decrease in relative humidity in NW China to increases in precipitation. NW China is characterized by an arid climate, and a reduction in precipitation will cause an increase in relative humidity.

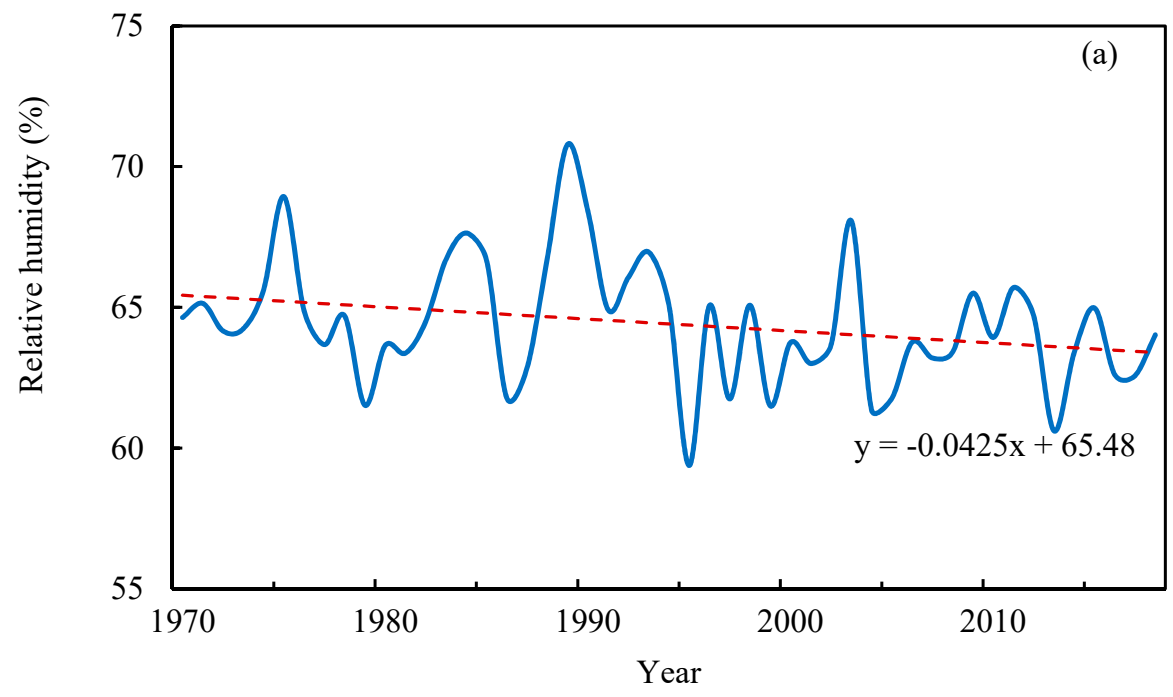

Figure 7. Cont. 

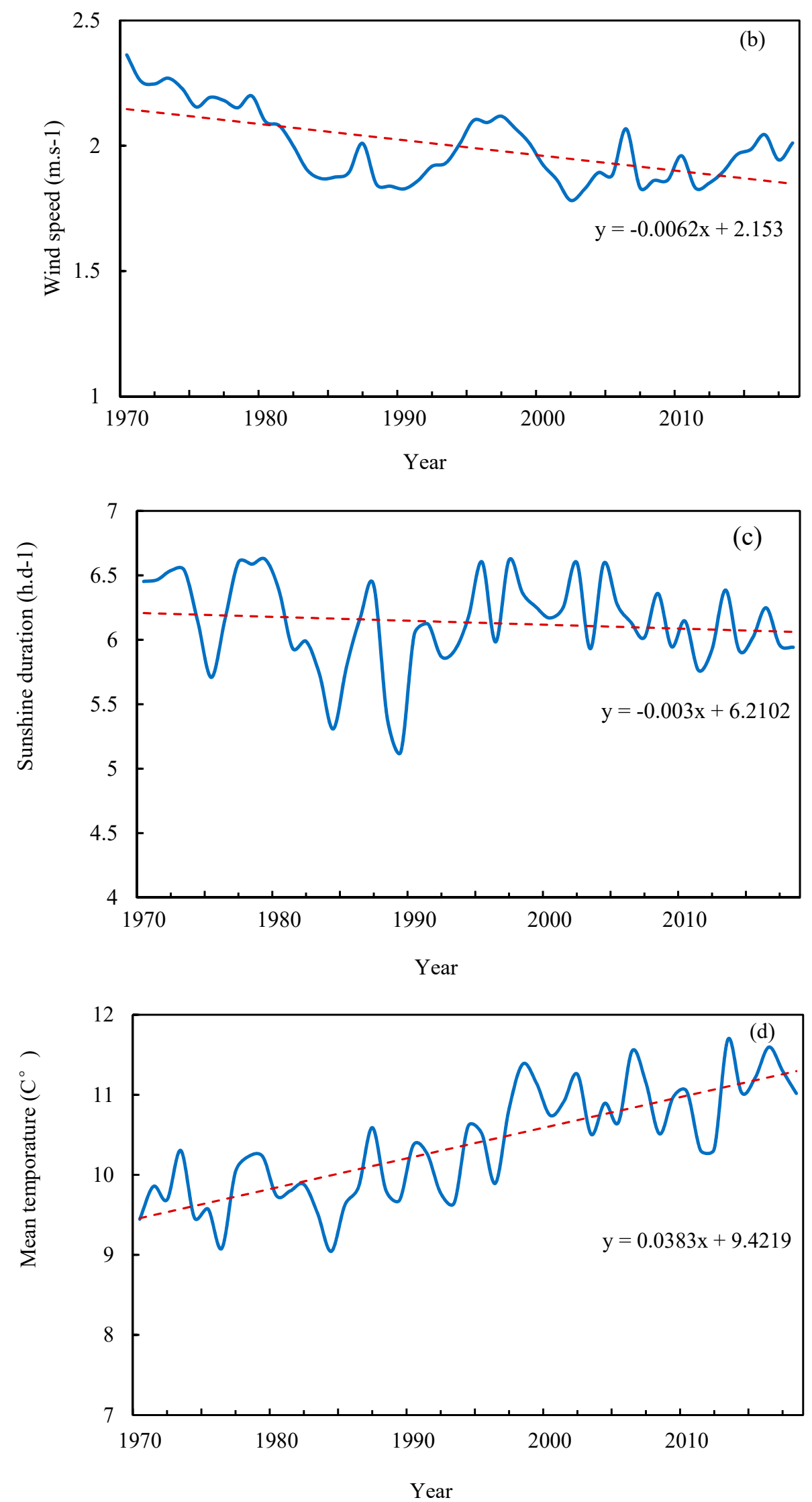

Figure 7. Annual trends of ((a): Relative humidity, (b): Wind speed, (c): Sunshine duration, (d): Mean temperature) in Weihe River Basin. 
Based on the previous results, it can be seen that the total contribution of meteorological factors to the $E T_{\mathrm{a}}$ changes is negative, but the $E T_{\mathrm{a}}$ in this study area is increasing. Therefore, the factors affecting the changes of $E T_{\mathrm{a}}$ in the WRB are complicated and comprehensive and are caused by a combination of climatic conditions and land surface conditions. Changes in precipitation are also closely related to changes in $E T_{a}$. Similar to the changes in the average multi-year $E T_{a}$, the precipitation changes also showed a slight increase (Figure 8). The spatial distribution of precipitation in the WRB is shown in Figure 9a, where it can be seen that precipitation in the WRB decreases from southeast to northwest. Similar changes can be observed in the average multi-year, summer, and autumn $E T_{\mathrm{a}}$ values. The precipitation in the WRB is mainly concentrated in summer and autumn, especially from June to August, indicating the $E T_{\mathrm{a}}$ in summer and autumn, to a certain extent, is affected by precipitation.

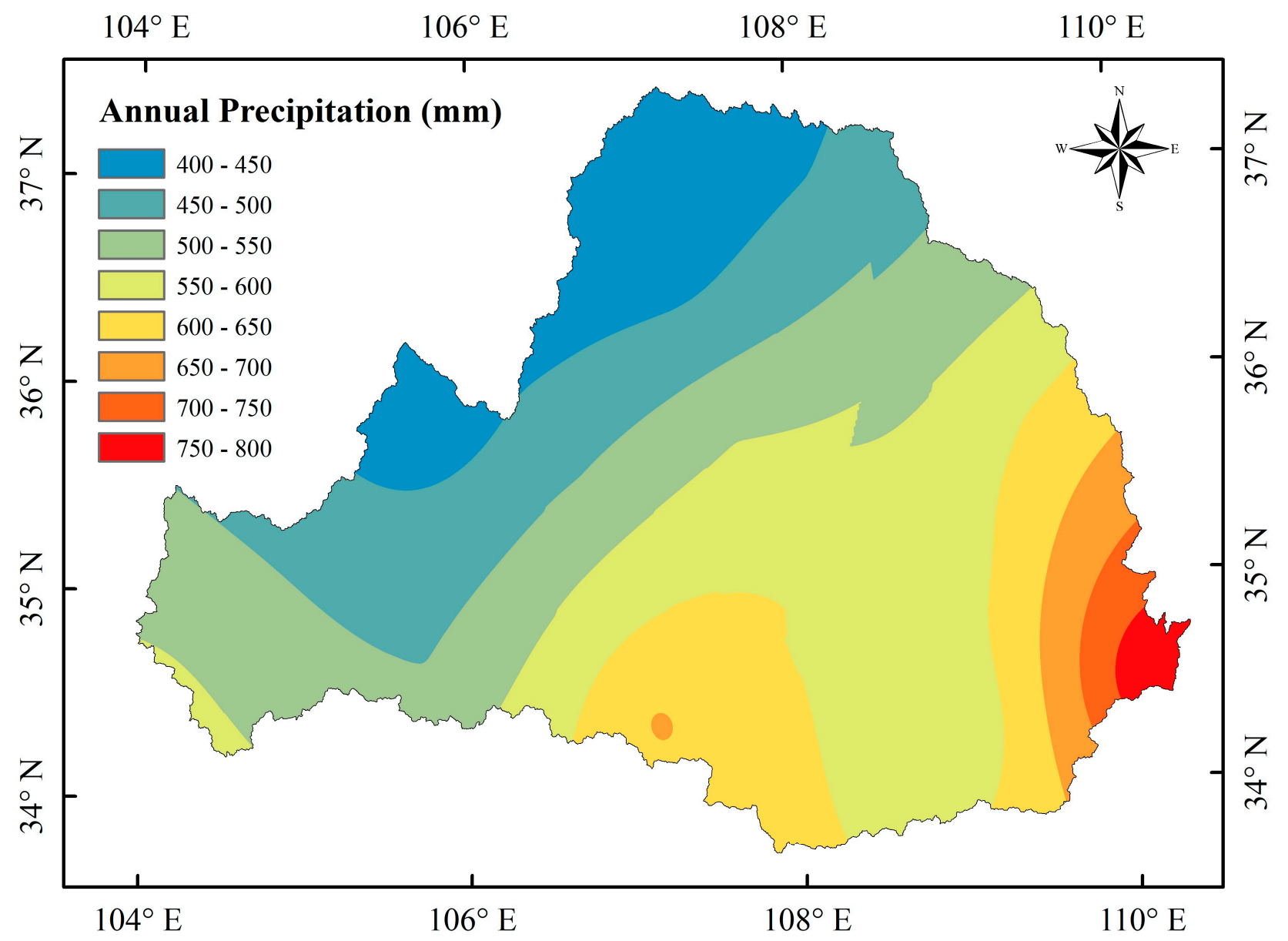

Figure 8. Spatial distribution of average precipitation from 1960-2018 in Weihe River Basin.

Rainfall mainly promotes evapotranspiration in two ways. On the one hand, it increases soil water content [68]. The decline in global land surface evapotranspiration from 1998 to 2008 was mainly due to the decrease of soil moisture [35]. On the other hand, rainfall can also promote vegetation growth. Using Pearson's correlation analysis, the correlation between precipitation and $E T_{\mathrm{a}}$ in the whole basin reached a significance level of $0.01(p=0.50)$, and the $E T_{\mathrm{a}}$ increased with an increase in precipitation. Evapotranspiration plays an important role in water and energy balance, and changes in evapotranspiration will also cause changes in the hydrological cycle. The Adridity index (AI) is usually used to evaluate the wet and dry state of a basin and is commonly expressed as the ratio of potential evapotranspiration to precipitation [69]. It can be seen from Figure $9 \mathrm{~b}$ that the climate in this basin is experiencing a state of long-term drought (AI greater than 1), although the AI presents opposite characteristics of 
change compared to the precipitation, as the overall trend of change is relatively gentle. There was, however, a significant increase in 1997 and 1995, mainly due to the decrease in rainfall during this period.
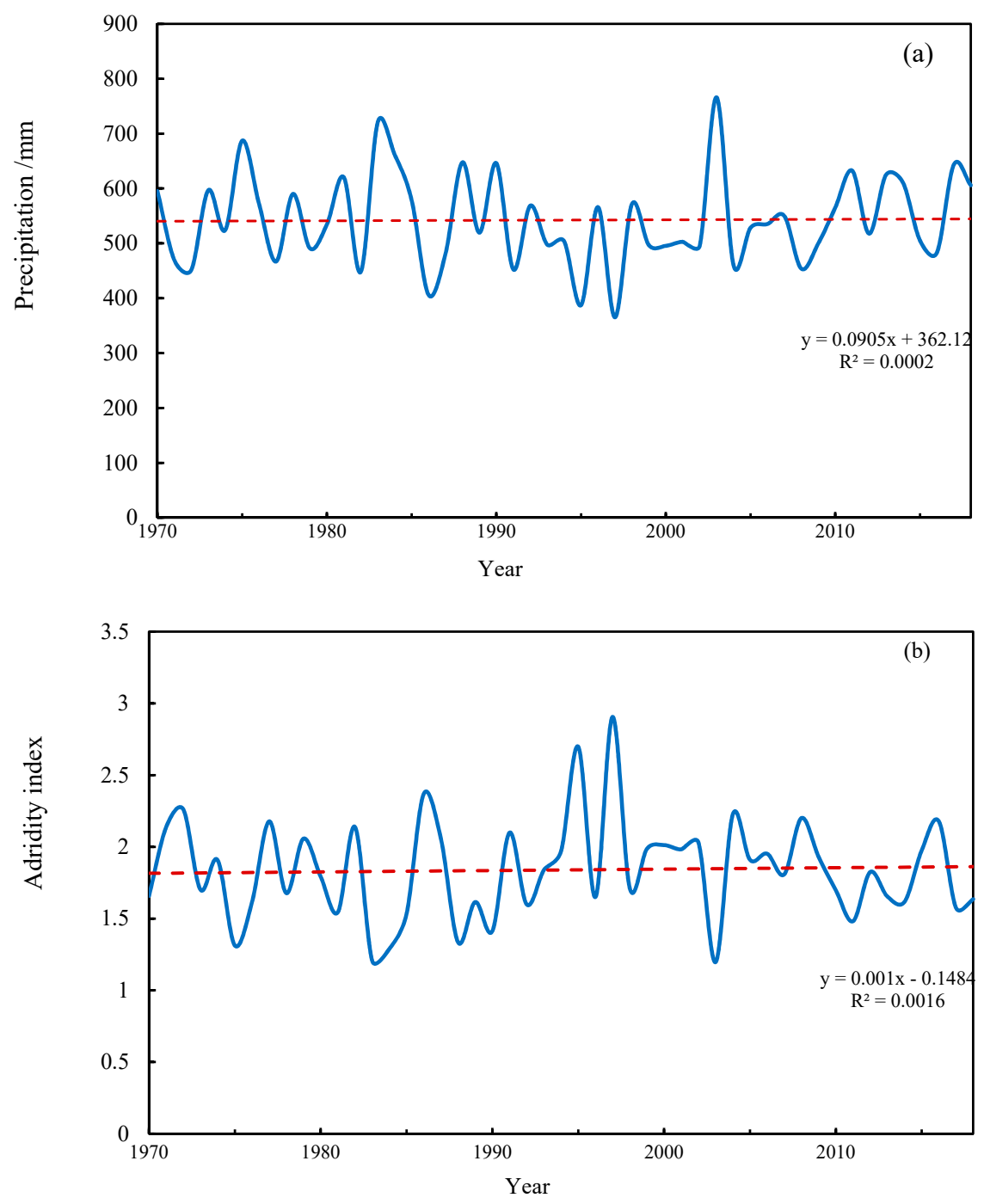

Figure 9. Variation of average precipitation and Adridity index from 1960-2018 in Weihe River Basin. (a): average precipitation; (b): Adridity index.

Some studies have also shown that vegetation change is another important factor affecting the changes of evapotranspiration in a watershed [70]. Since 1999, China has implemented a series of ecological restoration projects to alleviate ecological deterioration, such as surface water loss, soil erosion, land desertification, and grassland degradation. In particular, the implementation of large-scale Grain for Green and Nature Forest Protection programs resulted in the rapid restoration of vegetation in the WRB. The local climate has, therefore, changed, and the increase in the coverage of large areas of vegetation has further led to a rapid increase in local evapotranspiration [65]. Effective vegetation restoration resulted in a significant increase in evapotranspiration in the northeast and central parts of Xilinguole League, China [71]. Under the influence of the Grain for Green programs, the evapotranspiration in different catchments showed an increasing trend with the increase of vegetation coverage in the Loess Plateau of China. At the same time, these activities also caused changes in land use types in the watershed; likewise, the changes in evapotranspiration under different landscape patterns are different. Zhou et al. (2019) [56] estimated the $E T_{\mathrm{a}}$ of the Loess Plateau through MODIS data and found that the annual average evapotranspiration of different land use types in the Loess Plateau is forest land $>$ farmland $>$ grassland. The irrigation area of farmland is another 
important evapotranspiration area. Large areas of irrigated farmland (accounting for $72 \%$ of Shaanxi Province) and low-efficiency irrigation measures (flood irrigation) have caused a large amount of water to experience evapotranspiration.

In this study, the $E T_{\mathrm{a}}$ values estimated by the AA model were calibrated via the annual scale water balance method. The calculation of the runoff depth in terms of water balance was mainly based on the runoff data in the China Hydrological Yearbook. However, in this study we can only use the existing data to estimate the runoff depth, and some data are not available to the public. Therefore, without affecting the estimation, we used the water balance to estimate the runoff depth. Meanwhile, the measured runoff in recent years deviated from the "natural" runoff gradually, since the specific water amount used in reservoir storage and drainage, agricultural irrigation, and industrial domestic applications is difficult to estimate. In addition, this study focused on an analysis of the $E T_{\mathrm{a}}$ changes in the WRB based on meteorological factors but did not consider the adjustment of the crop planting belt, growth period changes, urban layout, or other related aspects caused by changes of meteorological factors.

\section{Conclusions}

This study calculated the $E T_{\mathrm{a}}$ of the WRB with the AA model based on complementary assumptions, and the water balance method was used to calibrate the parameters of the model. The estimated $E T_{\mathrm{a}}$ was in good agreement with the $E T_{\mathrm{a}}$ calculated by the water balance formulation. The $E T_{\mathrm{a}}$ in this basin showed a slight increasing trend in the long-term, and the spatial pattern of $E T_{\mathrm{a}}$ was shown to increase from northwest to southeast. In terms of spatial changes over the years, except for some stations in the southern part of the basin, the remaining stations showed a significant increase. Solar radiation is the most sensitive meteorological variable for $E T_{\mathrm{a}}$ changes in the basin, followed by actual vapor pressure, wind speed, and temperature. Actual vapor pressure is the meteorological variable that contributes the most to $E T_{\mathrm{a}}$ changes, followed by solar radiation. This indicates that the actual vapor pressure is the dominant factor that affects $E T_{\mathrm{a}}$ changes in the basin, in addition to climatic conditions, they are also affected by factors such as precipitation and landscape. This study provided a quantitative method to determine the relationship between meteorological variables and $E T_{\mathrm{a}}$. The results are vital for understanding the effects of climate and human activity on hydrological processes and provides important information for water resources management in China. However, due to the uncertainty and limitations of the study, to some extent there is still much work needed to obtain a more accurate actual evapotranspiration model. In the future, further research into the utilization forms of water resources in the basin and the issues related to climate resource changes and their environmental effects is needed.

Author Contributions: Conceptualization, X.M., P.G., and R.X.; methodology, X.M., P.G., R.X.; formal analysis, P.G., C.G.; resources, R.X., P.G.; data curation, R.X. and P.G.; writing-original draft preparation, R.X.; writing—review and editing, R.X., P.G., C.G.; visualization, R.X.; supervision, R.X., P.G., C.G.; project administration, X.M., P.G.; funding acquisition, P.G. All authors have read and agreed to the published version of the manuscript.

Funding: This research was funded by National Key Research and Development Program of China, Grant/Award Number: 2016YFC0501707.

Institutional Review Board Statement: Not applicable.

Informed Consent Statement: Not applicable.

Data Availability Statement: The daily series of meteorological data used in this study are avaliable on National Meteorological Information Centre of China (NMIC) (https:/ /www.nmic.cn/), while the data sharing of runoff are not applicable.

Acknowledgments: The authors acknowledge contributions from all members of the project team.

Conflicts of Interest: The authors declare no conflict of interest. 


\section{References}

1. Ohmura, A.; Wild, M. Is the Hydrological Cycle accelerating? Science 2002, 298, 1345-1346. [CrossRef]

2. Eckhardt, K. How to construct recursive digital filters for baseflow separation. Hydrol. Process. 2005, 19, 507-515. [CrossRef]

3. Potter, N.J.; Zhang, L. Water balance variability at the interstorm timescale. Water Resour. Res. 2007, 43, 5405. [CrossRef]

4. $\quad$ Budyko, M.I. Climate and Life; Academic Press: San Diego, CA, USA, 1974.

5. Fatichi, S.; Ivanov, V.Y. Interannual variability of evapotranspiration and vegetation productivity. Water Resour. Res. 2014, 50, 3275-3294. [CrossRef]

6. Javadian, M.; Behrangi, A.; Smith, W.K.; Fisher, J.B. Global Trends in Evapotranspiration Dominated by Increases across Large Cropland Regions. Remote Sens. 2020, 12, 1221. [CrossRef]

7. Ning, T.; Li, Z.; Feng, Q.; Chen, W.; Li, Z. Effects of forest cover change on catchment evapotranspiration variation in China. Hydrol. Process. 2020, 34, 2219-2228. [CrossRef]

8. Wang, D.; Alimohammadi, N. Responses of annual runoff, evaporation, and storage change to climate variability at the watershed scale. Water Resour. Res. 2012, 48, 5546. [CrossRef]

9. Trenberth, K.E.; Dai, A.; van der Schrier, G.; Jones, P.D.; Barichivich, J.; Briffa, K.R.; Sheffield, J. Global warming and changes in drought. Nat. Clim. Chang. 2013, 4, 17-22. [CrossRef]

10. Aminzadeh, M.; Roderick, M.L.; Or, D. A generalized complementary relationship between actual and potential evaporation defined by a reference surface temperature. Water Resour. Res. 2016, 52, 385-406. [CrossRef]

11. Aminzadeh, M.; Or, D. The complementary relationship between actual and potential evaporation for spatially heterogeneous surfaces. Water Resour. Res. 2017, 53, 580-601. [CrossRef]

12. Cohen, S.; Ianetz, A.; Stanhill, G. Evaporative climate changes at Bet Dagan, Israel, 1964-1998. Agric. For. Meteorol. 2002, 2, 83-91. [CrossRef]

13. Hobbins, M.T.; Ramirez, J.A.; Brown, T.C. Trends in pan evaporation and actual evapotranspiration across the conterminous US: Paradoxical or complementary? Geophys. Res. Lett. 2004, 31, 13. [CrossRef]

14. Tebakari, T.; Yoshitani, J.; Suvanpimol, C. Time-Space Trend Analysis in Pan Evaporation over Kingdom of Thailand. J. Hydrol. Eng. 2005, 10, 205-215. [CrossRef]

15. Moonena, A.C.; Ercoli, L.; Mariotti, M.; Masonib, A. Climate change in Italy indicated by agrometeorological indices over 122 years. Agric. For. Meteorol. 2002, 111, 13-27. [CrossRef]

16. Chattopadhyay, N.; Hulme, M. Evaporation and potential evapotranspiration in India under conditions of recent and future climate change. Agric. For. Meteorol. 1997, 87, 55-73. [CrossRef]

17. Roderick, M.L.; Farquhar, G.D. Changes in Australian pan evaporation from 1970 to 2002. Int. J. Climatol. 2004, 24, 1077-1090. [CrossRef]

18. Roderick, M.L.; Farquhar, G.D. Changes in New Zealand pan evaporation since the 1970s. Int. J. Climatol. 2005, 25, 2031-2039. [CrossRef]

19. Burn, D.H.; Hesch, N.M. Trends in evaporation for the Canadian Prairies. J. Hydrol. 2007, 336, 61-73. [CrossRef]

20. Asanuma, H.; Hishiya, T.; Komiyama, M. Efficient separation of hydrophobic molecules by molecularly imprinted cyclodextrin polymers. J. Incl. Phenom. Macrocycl. Chem. 2004, 50, 51-55. [CrossRef]

21. Cong, Z.T.; Yang, D.W.; Ni, G.H. Does evaporation paradox exist in China? Hydrol. Earth Syst. Sci. 2009, 13, 357-366. [CrossRef]

22. Yin, Y.; Wu, S.; Chen, G.; Dai, E. Attribution analyses of potential evapotranspiration changes in China since the 1960s. Theor. Appl. Climatol. 2009, 101, 19-28. [CrossRef]

23. Zuo, D.; Xu, Z.; Yang, H.; Liu, X. Spatiotemporal variations and abrupt changes of potential evapotranspiration and its sensitivity to key meteorological variables in the Wei River basin, China. Hydrol. Process. 2012, 26, 1149-1160. [CrossRef]

24. Roderick, M.L.; Farquhar, G.D. The Cause of Decreased Pan Evaporation over the Past 50 Years. Science 2002, $298,1140-1141$.

25. Wang, W.; Shao, Q.; Peng, S.; Xing, W.; Yang, T.; Luo, Y.; Yong, B.; Xu, J. Reference evapotranspiration change and the causes across the Yellow River Basin during 1957-2008 and their spatial and seasonal differences. Water Resour. Res. 2012, 48, 113-122. [CrossRef]

26. Xu, C.Y.; Gong, L.; Jiang, T.; Chen, D.; Singh, V.P. Analysis of spatial distribution and temporal trend of reference evapotranspiration and pan evaporation in Changjiang (Yangtze River) catchment. J. Hydrol. 2006, 327, 81-93. [CrossRef]

27. Shouhong, Z.; Chang, S.; Suxia, L.; Yang, S.; Xingguo, M.; Chun, Z. Assessing the Impact of Climate Change on Reference Evapotranspiration in Aksu River Basin. Acta Geogr. Sin. 2010, 65, 1363-1370.

28. Cao, G.; Han, D.; Song, X. Evaluating actual evapotranspiration and impacts of groundwater storage change in the North China Plain. Hydrol. Process. 2014, 28, 1797-1808. [CrossRef]

29. Yanjun, W.; Tong, J.; Bo, L. Trends of Estimated and Simulated Actual Evapotranspiration in the Yangtze River Basin. Acta Geogr. Sin. 2010, 65, 1079-1088.

30. Blatchford, M.L.; Mannaerts, C.M.; Njuki, S.M.; Nouri, H.; Zeng, Y.; Pelgrum, H.; Wonink, S.; Karimi, P. Evaluation of WaPOR V2 evapotranspiration products across Africa. Hydrol. Process. 2020, 34, 3200-3221. [CrossRef]

31. Jhajharia, D.; Shrivastava, S.K.; Sarkar, D.; Sarkar, S. Temporal characteristics of pan evaporation trends under the humid conditions of northeast India. Agric. For. Meteorol. 2009, 149, 763-770. [CrossRef]

32. Zheng, H.X.; Liu, X.M.; Liu, C.M.; Dai, X.Q.; Zhu, R.R. Assessing contributions to panevaporation trends in Haihe River Basin, China. J. Geophys. Res.-Atmos. 2009, 114, D24105. [CrossRef] 
33. Ninga, M.; Naianga, W.; Penglonga, W.; Yanmengb, S.; Chunyua, D. Temporal and Spatial Variation Characteristics and Quantification of the Affect Factors for Reference Evapotranspiration in Heihe River Basin. J. Nat. Resour. 2012, 27, 975-989.

34. Irmak, S.; Kabenge, I.; Skaggs, K.E.; Mutiibwa, D. Trend and magnitude of changes in climate variables and reference evapotranspiration over 116-yr period in the Platte River Basin, central Nebraska-USA. J. Hydrol. 2012, 420-421, 228-244. [CrossRef]

35. Jung, M.; Reichstein, M.; Ciais, P.; Seneviratne, S.I.; Sheffield, J.; Goulden, M.L.; Bonan, G.; Cescatti, A.; Chen, J.; de Jeu, R.; et al. Recent decline in the global land evapotranspiration trend due to limited moisture supply. Nature 2010, 467, 951-954. [CrossRef] [PubMed]

36. Shaomin, L.; Rui, S.; Zhongping, S.; Xiaowen, L.; Changming, L. Comparision of different complementary relationship models for regional evapotranspiration estimation. Acta Geogr. Sin. 2004, 59, 331-340.

37. Yanjun, W.; Liu, B.; Zhai, J.; Su, B.; Luo, Y.; Zhang, Z. Relationship Between Potential and Actual Evaporation in Yangtze River Basin. Adv. Clim. Chang. Res. 2011, 7, 1673-1719.

38. Hartmann, H.; Su, B.; Jiang, T.; Tao, H.; Sun, H.; Li, X.; Jian, D. Estimation of Actual Evapotranspiration by the Complementary Theory-Based Advection-Aridity Model in the Tarim River Basin, China. J. Hydrometeorol. 2018, 19, $289-303$.

39. Nakken, M. Wavelet analysis of rainfall-runoff variability isolating climatic from anthropogenic patterns. Environ. Model. Softw. 1999, 14, 283-295. [CrossRef]

40. Morton, F.I. Operational estimates of areal evapotranspiration and their significance to the science and practice of hydrology. J. Hydrol. 1983, 66, 1-76. [CrossRef]

41. Ramı'rez, J.A.; Hobbins, M.T. Observational evidence of the complementary relationship in regional evaporation lends strong support for Bouchet's hypothesis. Geophys. Res. Lett. 2005, 32, L15401. [CrossRef]

42. Yang, D.; Sun, F.; Liu, Z.; Cong, Z.; Lei, Z. Interpreting the complementary relationship in non-humid environments based on the Budyko and Penman hypotheses. Geophys. Res. Lett. 2006, 33, 33. [CrossRef]

43. Han, H.; Hou, J.; Huang, M.; Li, Z.; Xu, K.; Zhang, D.; Bai, G.; Wang, C. Impact of soil and water conservation measures and precipitation on streamflow in the middle and lower reaches of the Hulu River Basin, China. Catena 2020, 195, 1-10. [CrossRef]

44. Wang, Y.; Lu, H.; Wang, K.; Wang, Y.; Li, Y.; Clemens, S.; Lv, H.; Huang, Z.; Wang, H.; Hu, X.; et al. Combined high- and low-latitude forcing of east Asian monsoon precipitation variablity in the Pliocene warm period. Sci. Adv. 2020, 6, eabc2414. [CrossRef] [PubMed]

45. Gao, P.; Geissen, V.; Ritsema, C.J.; Mu, X.; Fei, W. Impact of climate change and anthropogenic activities on stream flow and sediment discharge in the Wei River basin, China. Hydrol. Earth Syst. Sci. 2013, 17, 961-972. [CrossRef]

46. Guo, A.; Chang, J.; Wang, Y.; Huang, Q.; Guo, Z.; Li, Y. Development of a partial copula-based algorithm for disclosing variability of dependence structures between hydro-meteorological factors under consideration of covariate-effect. J. Hydrol. $2020,583$. [CrossRef]

47. Brutsaert, W.; Stricker, H. An Advection-Aridity Approach to Estimate Actual Regional Evapotranspiration. Water Resour. Res. 1979, 15. [CrossRef]

48. Morton, F.I. Estimating Evaporation and Transpiration from Climatological Observations. J. Appl. Meteorol. 1975, $14,488$. [CrossRef]

49. Parlange, M.B.; Katul, G.G. Estimation of the diurnal variation of potential evaporation from a wet bare soil surface. J. Hydrol. 1992, 132, 71-89. [CrossRef]

50. Penman, H.L.; Keen, B.A. Natural evaporation from open water, bare soil and grass. Proc. R. Soc. Lond. Ser. A. Math. Phys. Sci. 1948, 193, 120-145.

51. Priesstley, C.H.B.; Taylor, R.J. On the Assessment of Surface Heat Flux and Evaporation Using Large-Scale Parameters. Mon. Weather Rev. 1972, 100, 81-92. [CrossRef]

52. Mann, H.B. Nonparametric tests against trend. Econometrica 1945, 13, 245-259. [CrossRef]

53. Kendall, M.G. Rank Correlation Measures; Charles Griffin: Oxford, UK, 1975.

54. Gao, P.; Deng, J.; Chai, X.; Mu, X.; Zhao, G.; Shao, H.; Sun, W. Dynamic sediment discharge in the Hekou-Longmen region of Yellow River and soil and water conservation implications. Sci. Total Env. 2017, 578, 56-66. [CrossRef]

55. Zhao, G.; Mu, X.; Wen, Z.; Wang, F.; Gao, P. Soil Erosion, Conservation, And Eco-Environment Changes In the Loess Plateau of China. Land Degrad. Dev. 2013, 24, 499-510. [CrossRef]

56. Zhou, Z.; Sun, W.; Mu, X.; Gao, P.; Zhao, G.; Song, X. Temporal and Spatial Pattern of Actual Evapotranspiration in the Loess Plateau from 2001 to 2017. Yellow River 2019, 41, 76-84.

57. Chong, J.; Fei, W.; Sijie, L.; Xingmin, M.; Rui, L.; Yanxu, L.; Chong, J. Evaporation paradox in the northern and southern regions of the Qinling Mountains. Acta Ecol. Sin. 2013, 33, 844-855. [CrossRef]

58. Liu, Q.; Yang, Z.; Cui, B.; Sun, T. The temporal trends of reference evapotranspiration and its sensitivity to key meteorological variables in the Yellow River Basin, China. Hydrol. Process. 2010, 24, 2171-2181. [CrossRef]

59. Liu, X.; Zheng, H.; Zhang, M.; Liu, C. Identification of dominant climate factor for pan evaporation trend in the Tibetan Plateau. J. Geogr. Sci. 2011, 21, 594-608. [CrossRef]

60. McVicar, T.R.; Van Niel, T.G.; Li, L.T.; Roderick, M.L.; Rayner, D.P.; Ricciardulli, L.; Donohue, R.J. Wind speed climatology and trends for Australia, 1975-2006: Capturing the stilling phenomenon and comparison with near-surface reanalysis output. Geophys. Res. Lett. 2008, 35, L20403. [CrossRef] 
61. Fan, Z.-X.; Thomas, A. Decadal changes of reference crop evapotranspiration attribution: Spatial and temporal variability over China 1960-2011. J. Hydrol. 2018, 560, 461-470. [CrossRef]

62. Xu, Y.; Xu, Y.P.; Wang, Y.F.; Wu, L.; Li, G.; Song, S. Spatial and temporal trends of reference crop evapotranspiration and its influential variables in Yangtze River Delta, eastern China. Theor. Appl. Climatol. 2017, 130, 945-958. [CrossRef]

63. Luo, K.; Tao, F.; Deng, X.; Moiwo, J.P. Changes in potential evapotranspiration and surface runoff in $1981-2010$ and the driving factors in Upper Heihe River Basin in Northwest China. Hydrol. Process. 2017, 31, 90-103. [CrossRef]

64. Zhao, Y.; Liu, Y.; LI, J.; Lliu, X. Spatial and Temporal Variation of Potential Evapotranspiration and Its Sensitivity to Meteorological Factors in China from 1960 to 2013. Desert Oasis Meteorol. 2018, 22, 3-14.

65. Fan, J.; Wu, L.; Zhang, F.; Xiang, Y.; Zheng, J. Climate change effects on reference crop evapotranspiration across different climatic zones of China during 1956-2015. J. Hydrol. 2016, 542, 923-937. [CrossRef]

66. Marshall, M.; Funk, C.; Michaelsen, J. Examining evapotranspiration trends in Africa. Clim. Dyn. 2012, 38, 1849-1865. [CrossRef]

67. Zhang, Q.; Xu, C.-Y.; Chen, X. Reference evapotranspiration changes in China: Natural processes or human influences? Theor. Appl. Climatol. 2010, 103, 479-488. [CrossRef]

68. Legesse, D.; Vallet-Coulomb, C.; Gasse, F. Hydrological response of a catchment to climate and land use changes in Tropical Africa: Case study South Central Ethiopia. J. Hydrol. 2003, 275, 67-85. [CrossRef]

69. Arora, V.K. The use of the aridity index to assess climate change effect on annual runoff. J. Hydrol. 2002, 265, 164-177. [CrossRef]

70. Cao, Q.; Yu, D.; Georgescu, M.; Han, Z.; Wu, J. Impacts of land use and land cover change on regional climate: A case study in the agro-pastoral transitional zone of China. Environ. Res. Lett. 2016, 10, 124025. [CrossRef]

71. Yu, D.; Li, X.; Cao, Q.; Hao, R.; Qiao, J. Impacts of climate variability and landscape pattern change on evapotranspiration in a grassland landscape mosaic. Hydrol. Process. 2019, 34, 1035-1051. [CrossRef] 